\title{
EFEITOS DO PROGRAMA INOVAR-AUTO SOBRE A INDÚSTRIA DE VEÍCULOS NO BRASIL
}

\author{
Thais Waideman Niquito * \\ André Carraro ${ }^{\dagger}$
}

\begin{abstract}
Resumo
O presente estudo analisa o efeito do programa Inovar-Auto sobre diversos indicadores da indústria de veículos no Brasil, buscando contribuir com a literatura nacional acerca da efetividade dos gastos tributários. Foram investigados os impactos sobre a produção de veículos, o pessoal ocupado, o custo das operações industriais, o ativo imobilizado e o valor adicionado. As estratégias empíricas adotadas foram a estimação modelos de controle sintético com dados nacionais e internacionais, bem como a estimação de um modelo de diferença em diferenças, com dados nacionais. Os impactos capturados sobre a produção e os ativos imobilizados não se mostraram robustos. Por outro lado, o impacto verificado sobre o valor adicionado foi negativo e há indícios de efeitos também negativos sobre o emprego e os custos.
\end{abstract}

Palavras-chave: Inovar-Auto, indústria de veículos, controle sintético, diferença em diferenças.

Códigos JEL: H25, L5, L62.

\begin{abstract}
This study analyzes the effect of the Inovar-Auto program on several indicators of the vehicle industry in Brazil, seeking to contribute to the national literature on the effectiveness of tax incentives. Impacts on vehicle production, employed persons, cost of industrial operations, fixed assets and added value were investigated. The empirical strategies adopted were the estimation of synthetic control models with national and international data, as well as the estimation of a model of difference in differences, with national data. The impacts captured on production and fixed assets were not robust. On the other hand, the impact on added value was negative and there are indications of negative effects on employment and costs.
\end{abstract}

Keywords: Inovar-Auto, vehicle industry, synthetic control, difference in differences.

JEL codes: H25, L5, L62.

DOI: http://dx.doi.org/10.11606/1980-5330/ea172674

\footnotetext{
* Professora Doutora da Universidade do Estado de Santa Catarina (UDESC) e do Programa de Pós-Graduação em Economia Aplicada da Universidade Federal do Rio Grande do Sul (PPGE/UFRGS). E-mail: twaideman@gmail.com.

† Professor Doutor do Programa de Pós-Graduação em Organizações e Mercados da Universidade Federal de Pelotas (PPGOM/UFPel).E-mail: andre.carraro@gmail.com.
} 


\section{Introdução}

Historicamente, políticas de exigência de conteúdo local têm sido uma ferramenta utilizada por diversos países em desenvolvimento para promover estímulos à produção e ao emprego em âmbito nacional. Apesar de não haver evidências robustas de sua eficácia, tal prática continua tendo significativa importância na formulação de políticas industriais, especialmente após momentos de crise, com potenciais efeitos na alocação dos fatores produtivos e impactos nos fluxos de comércio internacional (Stone et al. 2015).

Tais políticas, em geral, são engendradas a partir da concessão de subsídios associados à exigência de utilização de componentes locais (Grossman 1981). Do ponto de vista teórico, argumenta-se que as mesmas seriam neutras em termos fiscais, uma vez que a perdas decorridas dos gastos tributários seriam recompensadas pelo aumento da arrecadação advindo da expansão da produção e do emprego (Stone et al. 2015). Ainda, tais políticas são tidas como potenciais impulsionadoras da produção, do emprego e do desenvolvimento tecnológico de um setor específico (Kuntze \& Moerenhout 2012, Tordo et al. 2013).

Contudo, em um ambiente de mercados imperfeitos, é possível que o aumento da demanda por componentes locais eleve o preço dos insumos, dado que os fornecedores nacionais podem encontrar dificuldades tanto para ajustar seu volume de produção quanto para produzir componentes que atendam às exigências tecnológicas, com potenciais efeitos negativos no desempenho do setor alvo da política (Grossman 1981). Ademais, é sabido que diversas políticas podem gerar distorções na alocação de recursos produtivos entre firmas e setores, fenômeno cunhado misallocation (Hsieh \& Klenow 2009). Pode-se mencionar, por exemplo, aquelas políticas direcionadas a setores específicos, na forma de subsídios creditícios ou tributários. Ao gerarem heterogeneidade nos preços enfrentados pelos produtores, são reconhecidas fontes de misallocation, com potenciais efeitos negativos na produtividade agregada da economia (Bartelsman et al. 2013, Restuccia \& Rogerson 2008, 2017).

Se em termos teóricos o efeito de políticas de conteúdo local é ambíguo, são escassas as evidências empíricas de avaliação de seus impactos. Para o Brasil, uma exceção é o estudo desenvolvido por Possebom (2017), em que são avaliados os impactos econômicos da Zona Franca de Manaus, ${ }^{1}$ encontrando efeitos significativos sobre o PIB real e a produção total de serviços per capita, mas negativos sobre a produção agrícola per capita. O presente estudo visa contribuir para essa literatura, propondo-se a avaliar o Programa de Incentivo à Inovação Tecnológica e Adensamento da Cadeia Produtiva de Veículos Automotores (Inovar-Auto), criado pelo Governo brasileiro por meio da Lei $\mathrm{n}^{\circ}$ $12.715 / 2012$ na tentativa de reverter o fraco desempenho do setor e de promover sua competitividade.

Com grande relevância no cenário nacional - isoladamente, é responsável por $22 \%$ do Produto Industrial Bruto e por 3\% do Produto Interno Bruto do país, ${ }^{2}$ além de possuir extensa cadeia produtiva -, a indústria automobilística brasileira apresentou excelente desempenho no início dos anos 2000. Entre

\footnotetext{
${ }^{1}$ Entre 1975 e 1990, para receber os benefícios associados à Zona Franca de Manaus, as empresas deveriam não apenas estarem situadas em Manaus, mas também atenderem às exigências de conteúdo local (Possebom 2017).

${ }^{2}$ ANFAVEA - Associação Nacional dos Fabricantes de Veículos Automotores (2017, 2020).
} 
2002 e 2008, registrou crescimento anual médio superior a $10 \%$ na produção. ${ }^{3}$ Contudo, passou a experimentar dificuldades no período que sucedeu a crise financeira internacional. De 2009 a 2012, a produção do setor encolheu a uma taxa média de $1 \%$ ao ano. Em 2009, a participação do investimento sobre o faturamento foi de apenas 1,9\% e, em 2012, o setor registrou o quinto ano consecutivo de saldo negativo na balança comercial. ${ }^{4}$

Foi esse o contexto do surgimento do programa Inovar-Auto, que esteve em vigor entre os anos de 2013 a 2017, cuja principal medida foi instituir concessões de Crédito Presumido de Imposto sobre Produtos Industrializados (IPI) para empresas que, em pelo menos $80 \%$ da produção dos veículos fabricados, utilizassem $85 \%$ do valor com peças nacionais (Messa 2013). Expressamente, os principais objetivos do programa eram gerar estímulos aos investimentos, garantindo maior nacionalização dos veículos consumidos no país, e tornar a produção do setor mais competitiva em relação ao padrão internacional, em custo e tecnologia, por meio da capacitação de fornecedores e da realização de investimentos em P\&D (Brasil 2012).

Durante sua vigência, representou um gasto tributário total de $\mathrm{R} \$ 6,8$ bilhões - média de $\mathrm{R} \$ 1,35$ bilhões ao ano (valores nominais), o equivalente a $0,5 \%$ do total gastos tributários estimados para o período. ${ }^{5}$ Findo seu período de vigência, foi sucedido pelo programa Rota 2030, que tem como principal objetivo ampliar a inserção global da indústria automotiva nacional e atrela incentivos fiscais à investimentos em P\&D (Brasil 2018). Em linhas gerais, os impostos de importação de peças sem equivalente no Brasil (alíquota de $2 \%$ ) serão redirecionados para projetos de pesquisa, desenvolvimento e inovação. A estimativa é que o gasto com o novo programa seja em torno de $\mathrm{R} \$ 1$ bilhão nos cinco primeiros anos de vigência.

Apesar dos representativos montantes direcionais a tais políticas, são escassos estudos que façam a avaliação de seus impactos a partir dos instrumentos estatísticos adequados, não havendo evidências robustas de sua efetividade. A necessária racionalidade nos gastos públicos demanda que as políticas públicas sejam constantemente avaliadas, para que seus formuladores possam tomar as apropriadas decisões acerca de seus formatos ou até mesmo continuidade. Tal prática ainda não é rotineira no Brasil e o presente estudo objetiva contribuir nessa direção.

O intuito desta pesquisa é traçar um amplo panorama dos efeitos do programa Inovar-Auto sobre a indústria automobilística. Para tanto, são investigados os impactos sobre a produção de veículos, o pessoal ocupado, o custo das operações industriais, o ativo imobilizado (aquisições e melhorias) e o valor adicionado. Claramente, a análise de impacto de uma determinada política encontra como principal desafio a construção do cenário contrafactual, permitindo a observação do que teria ocorrido na ausência da mesma. Para tratar problemas dessa natureza, são documentadas na literatura diversas estratégias de identificação.

A principal estratégia empírica adotada no presente estudo foi a estimação de dois modelos de controle sintético. Primeiramente, utilizando dados internacionais obtidos junto à Organização Internacional das Indústrias de

\footnotetext{
${ }^{3}$ Instituto Brasileiro de Geografia e Estatística (IBGE)/Pesquisa Industrial Mensal-Produção Física (PIM-PF).

${ }^{4}$ ANFAVEA - Associação Nacional dos Fabricantes de Veículos Automotores (2020).

${ }^{5}$ Receita Federal, Demonstrativos dos Gastos Tributários, Bases Efetivas.
} 
Automóvel (OICA), foram investigados os impactos do programa sobre a produção de veículos. Nesse caso, o cenário contrafactual para a indústria de veículos brasileira foi construído criando-se um "Brasil Sintético" a partir de outros países. Contudo, é sabido que a economia brasileira foi afetada por uma severa crise entre 2014 e 2016 - nesse triênio, enquanto o PIB mundial cresceu a uma taxa anual média de 3,5\% (FMI), o brasileiro se retraiu a uma taxa anual média de $-2,1 \%$ (IBGE) -, o que pode ter afetado os resultados do setor automobilístico, dificultando o isolamento do impacto da política que se deseja avaliar.

Desse modo, em uma abordagem alternativa, foi estimado um segundo modelo de controle sintético com dados setoriais da indústria nacional, extraídos da Pesquisa Industrial Anual (PIA/IBGE), investigando-se os efeitos do programa sobre o pessoal ocupado, o custo das operações industriais, o ativo imobilizado e o valor adicionado. Nesse caso, o cenário contrafactual para a indústria de veículos foi construído a partir da combinação dos demais setores da indústria de transformação brasileira. Uma possível fragilidade dessa abordagem está no horizonte temporal de disponibilidade dos dados, cujo início data de 2007. Considerando-se que o Inovar-Auto começou em 2013, obtémse um período pré-tratamento de apenas seis anos, o que pode comprometer a consistência das estimativas (Abadie et al. 2010). Dessa forma, adicionalmente, como forma de checar a robustez dos resultados, foi estimado um modelo de diferença em diferenças a partir desse mesmo conjunto de dados.

O efeito estimado sobre a produção de veículos por meio do modelo de controle sintético e do uso dos dados de vários países foi negativo, mas não se mostrou robusto. Tanto construindo-se a unidade sintética utilizando como preditoras um conjunto de covariadas quanto apenas a variável dependente defasada, o efeito capturado para o Brasil não ficou na extremidade no teste de distribuição dos placebos. No modelo de controle sintético aplicado a dados setoriais nacionais, os resultados sobre o pessoal ocupado, os custos das operações industriais e o valor adicionado bruto foram negativos, mas apenas o terceiro se mostrou robusto. O efeito sobre o ativo imobilizado foi positivo, mas não robusto. A análise de robustez, assim como no caso anterior, foi conduzida, principalmente, a partir dos testes de distribuição dos placebos.

Por fim, os resultados alcançados a partir da estimação do modelo de diferença em diferenças corrobora com a direção do impacto do programa sobre as variáveis investigadas. A robustez, nesse caso, foi avaliada a partir da estimação de um placebo temporal, não sendo encontrada apenas para o impacto positivo observado sobre o ativo mobilizado. A redução dos custos, um efeito desejado do programa, se mostrou robusta. Adicionalmente, a queda no emprego e no valor adicionado, também robustas, poderiam ser entendidas como efeitos não desejados do programa. Contudo, levando-se em conta que o Brasil passou por uma severa crise econômica no período de vigência do Inovar-Auto, é razoável supor apenas que este não foi suficiente para reverter os efeitos da crise sobre o setor.

Assim, de maneira geral, pode-se concluir que o programa não teve efeitos sobre a produção de veículos e sobre o ativo imobilizado do setor, havendo indícios de que tenha reduzido os custos da indústria de veículos. Além disso, não foi capaz de reverter os efeitos negativos da crise que atingiu a economia brasileira nos anos de 2015 e 2016 sobre o emprego e o valor adicionado no setor de veículos, uma vez que há indícios de que o impacto sobre essas dimensões foi negativo. Este estudo é estruturado em mais quatro seções, além 
desta introdução. A seção 2 traz um breve panorama da indústria de veículos no Brasil e do programa Inovar-Auto. A seção 3 discute as bases de dados e as estratégias empíricas adotadas. Na seção 4 os resultados são apresentados e discutidos e a seção 5 traz as considerações finais.

\section{A Indústria de Veículos no Brasil e o Programa Inovar-Auto}

O surgimento da indústria de veículos no Brasil está associado ao fim da Primeira Guerra Mundial e ao crescimento econômico baseado na produção em massa de veículos à combustão. Desde as primeiras décadas do século XX, conforme destacam Marx \& Mello (2014), tal indústria evoluiu em quatro marcadas etapas. Inicialmente, dedicava-se à importação de automóveis, sem montagem local ou cadeias de suprimentos. Na segunda etapa, foram instaladas em território nacional montadoras dos principais players internacionais, abastecidas por fabricantes locais de autopeças. As importações tornaram-se restritas. Posteriormente, na terceira etapa - concomitante com a abertura comercial e o processo de estabilização macroeconômica nacional -, houve aumento do número de montadoras. Além disso, as políticas de liberalização e de incentivo a investimentos externos permitiram não apenas a importação de autopeças, mas também a participação da engenharia local em alguns projetos. Essa fase também é marcada pela importação de automóveis de segmento específico, como os de luxo e os de lançamento. Como destacado por Santos \& Pinhão (1999), a maior concorrência externa direcionou as montadoras para a redução de custos, racionalização das atividades, aumento da variedade de produtos e especialização das plantas. Por fim, na quarta etapa, houve aumento significativo de fábricas localmente instalada, que passaram a produzir internamente modelos que antes eram importados.

Ao longo desse período, construiu-se no país uma importante indústria automotiva, composta por 26 montadoras, 473 empresas fornecedoras de autopeças e 5.249 concessionárias (ANFAVEA - Associação Nacional dos Fabricantes de Veículos Automotores 2020). Em 2019, o Brasil produziu 2,94 milhões de veículos, o que representou $3,2 \%$ da produção mundial (OICA). O setor de fabricação de veículos automotores emprega diretamente cerca de 438 mil trabalhadores formais no país e as empresas estão majoritariamente situadas nas regiões Sul e Sudeste, que concentram quase $70 \%$ dos estabelecimentos (IBGE/PIA, 2018).

As frequentes políticas protecionistas direcionadas ao setor, que se seguiram principalmente a partir dos anos 1950, geraram uma indústria com reconhecida baixa produtividade, com preços elevados e com um processo de inovação praticamente inexistente (Sturgeon et al. 2017). Na tentativa de reduzir a concorrência externa, bem como em minorar desequilíbrio na balança comercial observada a partir de 2008, o Governo Federal instituiu, em 2013, o Inovar-Auto (Palmeri 2017). Ao ser lançado, o mesmo já possuía uma adesão maciça das empresas pertencentes à indústria automotiva brasileira. ${ }^{6}$

Conforme destacado por Sturgeon et al. (2017), o Inovar-Auto foi concebido para atender a dois objetivos estratégicos complementares. O primeiro consistia em atrair novos investimentos para o país, aumentando a capacidade

\footnotetext{
${ }^{6} \mathrm{O}$ quadro de empresas habilitadas ao programa pode ser visto em: http:// Www. mdic.gov.br/images/REP0SITORI0/sdc i / InovarAuto/Habili ta\%C3\%A7\%C3 \%B5es_Inovar_Auto_01062017.pdf.
} 
de produção da indústria, com esperados impactos positivos na geração de emprego e no aumento da produtividade do setor. Por sua vez, o segundo envolvia aproximar a indústria nacional dos novos patamares internacionais de regulação do setor, que indicavam, por exemplo, a produção de veículos com maior segurança, com mais eficiência energética e com o uso de mais tecnologia, refletidos em veículos movidos à energia elétrica, com acesso à internet $\mathrm{e}$ com a oferta de novos serviços de comunicação interligados a celulares. Assim, a investigação aqui conduzida busca averiguar o cumprimento dos objetivos do programa, tendo como limitação os dados disponíveis. São investigados nesta pesquisa os impactos sobre a produção de veículos, o pessoal ocupado, o valor adicionado, o custo das operações industriais e o ativo imobilizado.

Os gastos tributários estimados com o Inovar-Auto totalizaram, ao longo de seu período de vigência, aproximadamente $\mathrm{R} \$ 6,8$ bilhões, o que corresponde a pouco mais do que $0,5 \%$ do total de gastos tributários do período. Para se ter uma melhor dimensão relativa da magnitude dos gastos envolvidos com o Inovar-Auto, pode-se ilustrar, por exemplo, que o mesmo representou cerca de $5 \%$ dos gastos tributários direcionados ao setor industrial e de $12 \%$ daqueles direcionados às empresas industriais optantes pelo Simples Nacional. Além disso, o valor recebido ao longo da vigência do programa representou $1,8 \%$ do valor adicionado bruto da indústria de veículos automotores no mesmo período.

Tabela 1: Gastos tributários, Brasil, R \$ milhões correntes

\begin{tabular}{cccc}
\hline & Inovar-Auto $(\mathbf{A})$ & Total de Gastos Tributários $(\mathbf{B})$ & $(\mathbf{A}) /(\mathbf{B})$ \\
\hline 2013 & 852,54 & $223.310,47$ & $0,38 \%$ \\
2014 & $1.504,01$ & $257.223,37$ & $0,58 \%$ \\
2015 & $1.492,50$ & $269.993,56$ & $0,55 \%$ \\
2016 & $1.522,28$ & $264.686,81$ & $0,58 \%$ \\
2017 & $1.386,01$ & $278.743,06$ & $0,50 \%$ \\
\hline Total & $\mathbf{6 . 7 5 7 , 3 5}$ & $\mathbf{1 . 2 9 3 . 9 5 7 , 2 6}$ & $\mathbf{0 , 5 2 \%}$ \\
\hline
\end{tabular}

Fonte: Receita Federal, Demonstrativos dos Gastos Tributários, Bases Efetivas.

Em linhas gerais, o Inovar-Auto previa um aumento de 30 pontos percentuais na alíquota do Imposto sobre Produtos Industrializados (IPI) de veículos produzidos fora do Brasil, Mercosul ou México. Eram candidatas para habilitação no programa empresas que fabricassem ou importassem veículos, ou ainda que tivessem novos projetos de investimento para produção de veículos no país. Uma vez habilitadas, as empresas poderiam ter um crédito tributário referente a este aumento no IPI. Contudo, para usufruírem dos benefícios, as empresas participantes deveriam comprometer-se com uma série de contrapartidas, como, por exemplo, atingimento de metas de eficiência energética, realização de etapas fabris em território nacional e de dispêndios mínimos em pesquisa, desenvolvimento e inovação, entre outras. Além disso, o programa envolvia restrições à importação, com o estabelecimento de cotas (Brasil 2019). ${ }^{7}$

\footnotetext{
${ }^{7} \mathrm{O}$ regime automotivo do Inovar-Auto possui uma multiplicidade de regras que são diversas e complexas para diferentes segmentos de veículos. Aqui foram destacados apenas os itens mais gerais. Para uma visão mais detalhada, ver Brasil (2019).
} 
Dessa forma, é notório que as empresas domésticas passariam a ter um benefício competitivo em relação ao produto importado. Como consequência, o programa sofreu processos de montadoras estrangeiras com estratégia de atuação no mercado brasileiro de importação de veículos, que denunciaram o Governo brasileiro junto à Organização Mundial do Comércio (OMC). Um dos casos mais emblemáticos envolveu a denúncia feita pelo Governo japonês, em 2015. Na ocasião, alegou-se que o programa Inovar-Auto era discriminador com relação aos produtos de origem externa e que era, na verdade, uma política de subsídio ao setor automotivo doméstico. Em 2017, a OMC concluiu que o programa Inovar-Auto discriminava países, sendo uma política de gastos tributários, o que, conforme destacado por Myles et al. (2014), é um tipo de política cuja motivação é beneficiar um setor específico de um país.

Como já mencionado, encontram-se na literatura poucos estudos dedicados à avaliação dos impactos econômicos do programa Inovar-Auto a partir de um instrumental adequado. Duas exceções são os trabalhos realizados por Stone et al. (2015) e Messa (2013). Os primeiros autores conduziram uma ampla investigação, para vários países, acerca dos efeitos de Políticas de Conteúdo Local, a partir da aplicação de um modelo de equilíbrio geral computável. Destacam que, no caso do setor automotivo, a Rússia e a Venezuela adotaram políticas similares à brasileira após a crise de 2008.

Para o Brasil, a simulação dos impactos do programa Inovar-Auto conduzida por Stone et al. (2015) indicou uma projeção de aumento na produção de automóveis em 3,89\%, de redução no custo de produção em $0,06 \%$ e de aumento na demanda por trabalho em 3,81\%. Dadas as características do modelo empregado, é possível que esses resultados estejam capturando os impactos econômicos de curtíssimo prazo. Messa (2013), por sua vez, possui foco diferente do que se pretende nesta pesquisa. O autor avaliou o impacto do programa Inovar-Auto sobre o emprego nos setores fornecedores de componentes para a indústria automotiva. Utilizando o método de diferença em diferenças, não encontrou resultados que ratificassem a hipótese de que o mesmo tenha efeito positivo sobre o nível de emprego das empresas fornecedoras de componentes para o setor automobilístico.

A investigação do problema aqui proposta, com foco no setor diretamente afetado e conduzida por meio da aplicação das técnicas de avaliação de impacto consolidadas na literatura, contribui para uma visão mais ampla acerca dos efeitos da política, que são analisados de maneira ex-post, a partir dos resultados observados.

\section{Dados e Estratégia Empírica}

A estratégia de estimação dos impactos do programa Inovar-Auto via controle sintético foi adotada em dois contextos distintos. No primeiro modelo, o objetivo foi obter o efeito do programa sobre a produção de veículos no Brasil a partir de dados internacionais. Em linhas gerais, com base em um conjunto de informações para 36 países, ${ }^{8}$ foi construído um "Brasil sintético", servindo como cenário contrafactual para o cálculo do impacto do programa sobre a variável de interesse. Os dados de produção de veículos foram obtidos juntamente à Organização Internacional das Indústrias de Automóvel (OICA) e

\footnotetext{
${ }^{8}$ Na Tabela 2 da seção 4 , é possível a visualização de todos os países utilizados na estimação.
} 
se referem à produção total, levando em consideração tanto veículos de passageiros quanto comerciais. Como essa base de dados não contempla muitos países, quase todos disponíveis foram utilizados como candidatos à construção da trajetória sintética da produção de veículos no Brasil.

Para esta investigação, a unidade sintética foi construída de duas maneiras. Primeiramente, seguindo as práticas clássicas de Abadie \& Gardeazabal (2003), e Abadie et al. $(2010,2015)$ construiu-se a unidade sintética a partir de um conjunto de 14 covariadas, agregadas em nível nacional, extraídas das bases de dados do Banco Mundial e do Fundo Monetário Internacional (FMI), quais foram: (i) produto interno bruto (PIB) per capita, (ii) variação percentual anual do PIB, (iii) tamanho da força de trabalho, (iv) formação bruta de capital, (v) entrada líquida de investimento estrangeiro direto, (vi) inflação aos consumidores, (vii) poupança bruta, (viii) exportação de bens e serviços, (ix) importação de bens e serviços, $(\mathrm{x})$ despesa total do governo, (xi) participação da agricultura no total da economia, (xii) participação da indústria no total da economia, (xiii) consumo de energia elétrica e (xiv) taxa de participação da força de trabalho. Seguindo Abadie et al. (2010), a variável de interesse também foi utilizada como covariada para a construção do Brasil sintético. Em um segundo momento, como forma de testar a robustez dos resultados, adotou-se uma forma alternativa para a construção da unidade sintética, seguindo diversos estudos recentes que têm mostrado que o uso da variável de interesse defasada como preditora é capaz de produzir um bom ajuste para a construção da unidade sintética (ver, por exemplo, Botosaru \& Ferman (2019), Doudchenko \& Imbens (2016) e Gobillon \& Magnac (2016)). Em ambos os casos, o período de análise vai de 1999 a 2017, respeitando a disponibilidade dos dados.

O segundo modelo de controle sintético leva em conta dados setoriais da indústria nacional. Tal abordagem foi inserida no estudo como forma de atestar se os resultados encontrados a partir do uso de dados internacionais não teriam sido afetados pela crise econômica que atingiu o Brasil entre 2014 e 2016, conforme mencionado na introdução. Nesse caso, o setor de fabricação de veículos automotores, reboques e carrocerias foi considerado como tratado - ou seja, afetado pelo programa - e os demais 23 setores da indústria de transformação brasileira foram candidatos à construção de sua unidade sintética. ${ }^{9}$ Foram utilizadas exclusivamente as informações disponibilizadas pelo Instituto Brasileiro de Geografia e Estatística (IBGE) por meio da Pesquisa Industrial Anual (PIA-Empresa), para os anos de 2007 a 2016. ${ }^{10}$ A partir dessa abordagem, foram avaliados os efeitos sobre quatro variáveis extraídas da base de dados supracitada: (i) o número de pessoas ocupadas em 31/12, (ii) o valor adicionado bruto, (iii) os custos das operações industriais e (iv) o ativo imobilizado (aquisições e melhorias).

Cabe aqui conceituar as variáveis de interesse analisadas. O número de pessoas ocupadas em 31/12 se refere ao total de pessoas vinculadas ao setor no último dia de cada ano, incluindo aquelas afastadas para férias, licenças, seguros por acidentes, entre outros, mesmo que os afastamentos sejam superi-

\footnotetext{
${ }^{9}$ Foi utilizada a divisão setorial da Classificação Nacional de Atividades Econômicas (CNAE), versão 2.0. A mesma pode ser encontrada em: https : / / concla.ibge.gov.br/.

${ }^{10}$ Embora os dados da PIA-Empresa estejam disponíveis desde 1996, no ano de 2007 houve mudança na classificação de atividade, passando da CNAE 1.0 para a CNAE 2.0. Como os dados disponibilizados pelo IBGE em nível mais agregado não permitem que se remonte a exata correspondência setorial entre as duas versões, optou-se por iniciar a série de dados neste ano.
} 
ores a 15 dias. Não são contabilizados os membros do conselho administrativo, diretor ou fiscal, que não desenvolvam qualquer outra atividade na empresa, os autônomos e as pessoas que trabalham dentro da empresa, mas são remuneradas por outras empresas. $\mathrm{O}$ valor adicionado bruto é a diferença entre o valor bruto da produção e o consumo intermediário. Conforme mencionado na seção 2 , a investigação dessas duas variáveis, em conjunto com a investigação feita sobre a produção a partir de dados internacionais, visam avaliar se o Inovar-Auto foi capaz de atrair novos investimentos, expandir a capacidade produtiva e o emprego, parte do objetivo da política.

O custo das operações industriais compreende os custos incorridos no ano que estão diretamente ligados à produção (consumo de matérias-primas, materiais auxiliares e componentes; compra de energia elétrica; consumo de combustíveis, de peças e acessórios para manutenção e reparação de máquinas e equipamentos, serviços industriais e de manutenção e reparação de máquinas e equipamentos prestados por terceiros). Os salários e encargos não estão inseridos nesses custos. Já o ativo imobilizado é a quantidade de recursos aplicados no ano para aquisição de bens de permanência duradoura destinados ao funcionamento da empresa e para melhorias (benfeitorias) que tenham aumentado a vida útil dos bens. Logo, entende-se que a investigação dos efeitos do programa sobre essas variáveis pode dar indicativos da capacidade de as empresas cumprirem o objetivo de aproximação da indústria nacional em relação aos patamares internacionais, por meio da redução dos custos para a produção e do aumento do estoque de capital.

Assim como procedido na estimação a partir dos dados internacionais, na investigação a partir dos dados setoriais nacionais, a unidade sintética também foi construída de duas maneiras. Primeiramente, para cada uma das variáveis de interesse, ela própria e as outras investigadas, além do número de empresas, foram utilizadas como preditores. Em um segundo momento, para cada variável de interesse, apenas os seus valores defasados foram utilizados como preditores. Ainda como forma de atestar a robustez dos resultados, adotou-se uma terceira estratégia empírica, que consiste na estimação de um modelo de diferença em diferenças, no qual são usadas as mesmas informações do modelo de controle sintético com dados setoriais para a indústria nacional, investigando-se os impactos do Inovar-Auto sobre as quatro variáveis supracitadas. As subseções 3.1 e 3.2 apresentam em maior detalhe as estratégias empíricas adotadas.

\subsection{Modelo de Controle Sintético}

Esta subseção discute o método de controle sintético, utilizado para analisar o impacto do programa Inovar-Auto sobre a produção de veículos no Brasil, a partir de uma base de dados internacional, e sobre o pessoal ocupado, os custos, os ativos e o valor adicionado desta indústria, a partir de uma base de dados setorial nacional.

Nesta abordagem empírica, constrói-se para o país (Brasil) ou setor (veículos) que foi afetado (tratado) pelo programa a trajetória das variáveis de interesse na ausência da intervenção (tratamento) - denominada "trajetória sintética". Isso é feito tendo como base o comportamento de algumas variáveis, correlacionadas com as de interesse, nos países (ou setores) que não receberam o tratamento (controles). A forma por meio da qual a trajetória sintética é construída faz com que a mesma não esteja sujeita aos efeitos do tratamento, 
servindo, portanto, como o cenário contrafactual para a avaliação dos impactos.

A ideia subjacente ao método para a identificação do impacto e do estabelecimento da relação causal é que o processo que gera a trajetória da variável de interesse no país (ou setor) tratado é o mesmo que gera essa trajetória nas unidades de controle. Consequentemente, choques ocorridos no período investigado (que não a intervenção) afetam similarmente as variáveis dependentes em todas as unidades. Abaixo, o método é apresentado formalmente, seguindo de perto o desenvolvido em Abadie et al. (2010), cujo objetivo foi calcular o impacto do programa de controle do tabagismo, implantado na Califórnia em 1988.

Suponha que existam no mundo $C+1$ países (ou, na indústria, $C+1$ setores) sendo que apenas o primeiro tenha sido exposto ao tratamento, remanescendo $C$ países (setores) como potenciais controles. Define-se $Y_{m t}^{N}$ como a variável de interesse do país (setor) $m$ no instante $t$ na ausência da implementação do programa para $m=1, \ldots, C+1$ e $t=1, \ldots, T$. Define-se $T_{0}$ como o número de períodos pré-programa, com $1<T_{0}<T$. Além disso, seja $Y_{m t}^{I}$ a variável de interesse do país (setor) $m$ no instante $t$ quando o mesmo foi afetado pelo programa nos períodos $T_{0}+1$ até $T$. Assume-se também que a criação do Inovar-Auto não teve impactos sobre a variável de interesse antes do ano de sua implantação, assim para $t \in\left\{1, \ldots, T_{0}\right\}$ e para todo $m \in\{1, \ldots, N\}$, tem-se que $Y_{m t}^{I}=Y_{m t}^{N}$.

Seja $\alpha_{m t}=Y_{m t}^{I}-Y_{m t}^{N}$ o efeito do programa nas variáveis de interesse no país (setor) $m$ no tempo $t$ e seja $D_{m t}$ uma variável binária que assume valor 1 para períodos em que o país (setor) foi exposto ao tratamento e 0 para os períodos anteriores. Assim, a variável de interesse observada no país (setor) $m$ no tempo $t$ é dado por:

$$
Y_{m t}^{I}=Y_{m t}^{N}+\alpha_{m t} D_{m t}
$$

Uma vez que apenas o primeiro país - país "um" (ou setor - setor "um") foi exposto à criação do programa Inovar-Auto e a medida somente teve impacto após o ano de sua implantação $\left(T_{0}\right)$, tem-se que:

$$
D_{m t}= \begin{cases}1, & \text { se } m=1 \text { e } t>T_{0} \\ 0, & \text { caso contrário }\end{cases}
$$

Os parâmetros de interesse para estimação do impacto do tratamento sobre as variáveis de interesse do país (setor) tratado são $\left(\alpha_{1 T_{0+1}}, \ldots, \alpha_{1 T}\right)$. Notase claramente que $Y_{m t}^{I}$ é observado para todos os períodos, enquanto que não se observa $Y_{m t}^{N}$ para o país (setor) tratado nos períodos posteriores à implantação do programa. Portanto, para a estimação dos parâmetros de interesse, faz-se necessária a estimação de $Y_{m t}^{N}$.

Suponha que $Y_{m t}^{N}$ seja dado por um modelo fatorial, na forma:

$$
Y_{m t}^{N}=\delta_{t}+\theta_{t} Z_{m}+\lambda_{t} \mu_{m}+\epsilon_{m t}
$$

em que $\delta_{t}$ é um fator desconhecido comum entre os países (setores); $Z_{m}$ é um vetor $(r \times 1)$ de variáveis previsoras daquelas de interesse; $\theta_{t}$ é um vetor $(1 \times r)$ 
de parâmetros; $\lambda_{t}$ é um vetor $(1 \times F)$ de fatores comuns não observáveis; $\mu_{m}$ é um vetor $(F \times 1)$ de fatores desconhecidos; e $\epsilon_{m t}$ é o termo de erro com média zero para $m$ e $t$.

Agora, considere um vetor de pesos $P(C \times 1)$ tal que $P=\left(p_{2}, p_{3}, \ldots, p_{C+1}\right)^{\prime}$, $p_{m} \geq 0$ para $m=2, \ldots, C+1$ e $\sum_{m=2}^{C+1} p_{m}=1$. Cada valor particular do vetor $P$ representa um potencial controle sintético, de modo que o vetor $P$ gera uma média ponderada específica dos países (setores) candidatos a controle. Desse modo, a variável de interesse sintética pode ser expressa por:

$$
\sum_{m=2}^{C+1} p_{m} Y_{m t}=\delta_{t}+\theta_{t} \sum_{m=2}^{C+1} p_{m} Z_{m t}+\lambda_{t} \sum_{m=2}^{C+1} p_{m} \mu_{m}+\sum_{m=2}^{C+1} p_{m} \epsilon_{m t}
$$

Supondo que haja um $P^{*}=\left(p_{2}^{*}, p_{3}^{*}, \ldots, p_{C+1}^{*}\right)^{\prime}$ que satisfaça $\sum_{m=2}^{C+1} p_{m}^{*}=1 \mathrm{e}$ que:

$$
\begin{gathered}
\sum_{m=2}^{C+1} p_{m}^{*} Y_{m t}=Y_{1 t} \forall t \in\left(t, T_{0}\right) \\
\sum_{m=2}^{C+1} p_{m}^{*} Z_{m t}=Z_{1}
\end{gathered}
$$

pode ser mostrado que se $\sum_{t=1}^{T_{0}} \lambda_{t}^{\prime} \lambda_{t}$ é não singular:

$$
\begin{aligned}
Y_{1 t}^{N}-\sum_{m=2}^{C+1} p_{m}^{*} Y_{m t} & =\sum_{m=2}^{C+1} p_{m}^{*} \sum_{s=1}^{T_{0}} \lambda_{t}\left(\sum_{n=1}^{T_{0}} \lambda_{n}^{\prime} \lambda_{n}\right)^{-1} \lambda_{s}^{\prime}\left(\epsilon_{m s}-\epsilon_{1 s}\right) \\
& -\sum_{m=2}^{C+1} p_{m}^{*}\left(\epsilon_{m s}-\epsilon_{1 s}\right)
\end{aligned}
$$

Se o número de períodos anteriores ao programa for grande em relação à escalada de $\epsilon$, Abadie et al. (2010) demonstram que, sob certas condições, o lado direito da equação (7) se aproxima de zero, permitindo que o parâmetro de interesse seja estimado na forma:

$$
\hat{\alpha}_{1 t}=Y_{1 t}^{I}-\sum_{m=2}^{C+1} p_{m}^{*} Y_{m t} \forall t \in\left(T_{0}, T\right]
$$

É bastante provável que as equações (5) e (6) não sejam obtidas para nenhum $P$. Em outras palavras, o país (setor) tratado não pode ser replicado com exatidão por nenhuma combinação de médias ponderadas dos países (setores) de controle. Contudo, o método de controle sintético consiste em buscar os pesos que tornam a média ponderada dos países (setores) de controle o mais próximo possível do país (setor) tratado.

Seja $X_{0}$ um vetor $(K \times 1)$ em que $K$ são os valores de variáveis pré-tratamento associadas ao país (setor) que implementou o programa, $X_{1}$ uma matriz $(K \times C)$ 
que contém os valores das mesmas variáveis de $X_{0}$, mas para todos os $C$ países (setores) candidatos à controle, e $W$ uma matriz diagonal cujos valores na diagonal refletem a importância que cada variável pré-tratamento recebe na predição da variável de interesse. O vetor de pesos $P^{*}$ será escolhido de modo a resolver o seguinte problema de otimização condicionada:

$$
\min _{p \in P}\left(X_{0}-X_{1} P\right)^{\prime} W\left(X_{0}-X_{1} P\right)
$$

em que: $P=\left\{\left(p_{2}, \ldots, p_{C}\right)^{\prime}\right.$ sujeito a: $\left.\sum_{m=2}^{C} p_{m}=1, p_{m} \geq 0(m=2, \ldots, C)\right\}$

O vetor $P^{*}$, obtido da resolução do problema acima exposto, contém o peso ótimo estimado que cada um dos países (setores) candidatos a controle deve receber para a construção do contrafactual. É importante mencionar que alguns candidatos a controle podem receber peso zero devido à sua capacidade nula em auxiliar na construção da unidade sintética.

Assim, a unidade sintética será o mais próximo possível da unidade tratada, em termos da variável de interesse. Uma medida de ajuste da unidade construída com a unidade tratada é a Raiz do Erro de Previsão Quadrático Médio (REPQM), que é a raiz quadrada do erro quadrático médio, de modo que valores mais próximos de zero indicam ajustes melhores entre as unidades.

Conforme destaca Abadie \& Gardeazabal (2003), o vetor $P^{*}$ dependerá da importância relativa que é atribuída a cada variável utilizada na predição da variável de interesse (valores de $W$ ). Essa escolha pode ser feita de maneira arbitrária. Contudo, no presente estudo, a determinação de $W$ será realizada com base em um processo de otimização que procura dentre todas as matrizes diagonais positivas semidefinidas aquela que gere os pesos que melhor se ajustem às informações do país (setor) tratado com os países (setores) de controle.

Uma vez obtida a matriz $P^{*}$, a construção da variável de interesse para a unidade sintética é a média ponderada do valor dessa variável para cada unidade de controle por seu peso ótimo estimado. Essa é a série utilizada para fins de comparação com a real trajetória da variável de interesse no país (setor) tratado de fato.

Assim, se $Y_{m t}$ é a variável de interesse para $m=2, \ldots, C+1$ nos $T$ períodos de análise, tem-se que as estimativas da trajetória da variável de interesse sintética, $Y_{1 t}^{N}$, e do impacto da implementação do programa Inovar-Auto no Brasil - país "um" (ou no setor de Veículos Automotores - setor "um"), $\alpha_{1}$, para todos os períodos $t \in\left(T_{0}, T\right]$ são dadas por:

$$
\begin{gathered}
\hat{Y}_{1 t}^{N}=\sum_{m=2}^{C+1} p_{m}^{*} Y_{m t} \\
\hat{\alpha}_{1 t}=Y_{1 t}^{I}-\hat{Y}_{1 t}^{N}
\end{gathered}
$$

Como visto, a ideia central do método de controle sintético é que uma combinação dos países (setores) não afetados pela política econômica fornece um 
cenário contrafactual melhor do que uma única unidade isolada. De acordo com Abadie et al. (2010), a transparência é uma das características mais atrativas do método aqui proposto, uma vez que deixa explícita a contribuição relativa de cada unidade de controle na criação do cenário contrafactual, bem como as similaridades entre as unidades de tratamento e controle.

\subsection{Modelo de Diferença em Diferenças}

Como estratégia empírica adicional, o impacto do Inovar-Auto sobre a indústria de veículos no Brasil também foi estimado por meio de um modelo de diferença em diferenças tendo como base os dados setoriais da indústria de transformação nacional. A ideia subjacente desse método é mensurar as diferenças entre a unidade tratada (setor de veículos) e aquelas não tratadas, denominadas controles (os demais 23 setores da indústria de transformação), em dois períodos de tempo (pré-implementação do programa - 2007 a 2012 e pós-implementação - 2013 a 2016).

A equação a ser estimada é a seguinte:

$$
y_{s t}=k_{s}+\pi_{t}+\alpha_{1} \text { InovarAuto }_{s t}+\alpha_{2} \text { Empresas }_{s t}+\rho_{s} t+\epsilon_{s t}
$$

em que a variável $y_{s t}$ representa uma das quatro variáveis sobre as quais o impacto foi investigado para o setor $s$ no ano $t ; k_{s}$ é o efeito fixo do setor $s$; e $\pi_{t}$ é um vetor com dummies de ano. A variável InovarAuto ${ }_{s t}$ é binária, assumindo valor um quando a observação $s$ é o setor de fabricação de veículos e quando o ano $t$ for de 2013 em diante (vigência do programa). No modelo também foi inserida a covariada número de empresas no setor, representada na equação por Empresas $_{s t}$ e uma tendência linear específica de cada setor, representada pelo termo $\rho_{s} t$. Por fim, $\epsilon_{s t}$ é o termo de erro. Cabe ressaltar que, na seção de resultados, também são apresentadas as estimações sem a covariada e a tendência linear setorial.

Assim, a equação (11) foi estimada quatro vezes, para cada uma das variáveis de interesse. Além disso, seguindo a recomendação de Bertrand et al. (2004), as estimações foram feitas com cluster de setores, de modo a corrigir problemas de heterocedasticidade do termo de erro e de superestimação da significância dos coeficientes.

O modelo de diferença em diferenças tem como pressuposto a hipótese de que na ausência de tratamento os grupos tratados e controles evoluiriam de maneira semelhante, também denominada hipótese de tendências paralelas. Na literatura, frequentemente a validade de tal hipótese é testada via realização de testes placebos temporais. Nesses caso, o mais usual é supor a existência de tratamento em algum período que se sabe que este não ocorreu e estimar o efeito da política em escrutínio, esperando que os parâmetros resultantes não sejam estatisticamente significativos. O teste de placebo temporal aqui realizado é apresentado na seção de resultados.

\section{Resultados e Discussão}

Nesta seção, são apresentados e discutidos os resultados obtidos a partir das três estratégias empíricas adotadas. A subseção 4.1 traz os efeitos encontrados a partir da estimação do modelo de controle sintético com dados internacionais, com a comparação da produção da indústria de veículos no Brasil 
com outros países. A subseção 4.2 apresenta os efeitos obtidos por meio da estimação via controle sintético que leva em conta dados nacionais setoriais, comparando o setor de veículos com os demais da indústria de transformação brasileira. A subseção 4.3 traz os impactos do programa estimados a partir do modelo de diferença em diferenças, também estimado com dados setoriais da indústria nacional.

De maneira sucinta, o efeito estimado sobre a produção de veículos - por meio do modelo de controle sintético e do uso dos dados de vários países não se mostrou robusto. Com o modelo de controle sintético aplicado a dados setoriais nacionais foram estimados os efeitos sobre o pessoal ocupado, o custo das operações industriais, o ativo imobilizado (aquisições e melhorias) e o valor adicionado. Os resultados também não foram robustos, não sendo possível afirmar que o programa tenha tido efeito sobre essas variáveis. Apenas no caso do valor adicionado, os impactos (negativos) apresentaram robustez nas duas abordagens empregadas, mas somente nos anos finais da série. Assim, esse resultado precisa ser lido com cautela, visto que, nesse período, o Brasil atravessava uma severa crise econômica, que pode ter influenciado o comportamento da variável investigada caso tenha atingido o setor de veículos mais duramente que os demais segmentos da indústria de transformação.

Por fim, os resultados do modelo de diferença em diferenças mostraram que o Inovar-Auto reduziu os custos das operações industriais, o que pode ser considerado um impacto positivo do programa. Contudo, também há evidências de redução do pessoal ocupado e do valor adicionado bruto, que se mostraram crescentes com o passar dos anos. Novamente, cautela é necessária na leitura desses resultados.

\subsection{Resultados do Modelo de Controle Sintético para a Comparação entre Países (Internacional)}

A Tabela 2 apresenta os pesos que cada um dos 36 países candidatos a controle recebeu para a construção do Brasil sintético. A unidade sintética foi criada a partir da seguinte ponderação: Argentina $(18,7 \%)$, China $(33,7 \%)$, França $(42,2 \%)$, Japão $(0,1 \%)$ e Turquia $(5,3 \%)$. Na Tabela 3 , são trazidas as médias para o período de pré-tratamento das variáveis analisadas do Brasil e seu sintético. Assim, é possível comparar o quão preciso foi o método em reproduzir as médias pré-tratamento das variáveis preditoras. Pode-se observar que, na média do período de 1999 a 2012, o PIB per capita do Brasil foi de cerca de US\$ 13 mil, a economia do país cresceu a uma taxa anual de 3,5\% e a força de trabalho era composta por 90 milhões de pessoas, representando cerca de $66 \%$ da população. A formação bruta de capital representava pouco mais de $19 \%$ do PIB, a entrada líquida de investimento estrangeiro direto era de apenas $3,19 \%$ do PIB e a taxa de poupança representava pouco menos de $16 \%$ do PIB. O país apresentava baixas taxas de exportação e importação, respectivamente $12,81 \%$ e $12,53 \%$ do PIB. Por fim, o setor primário era responsável por 5,58\% do PIB e a indústria por pouco mais de $27 \%$ do PIB, sendo o restante advindo do setor de serviços.

A média ponderada a partir dos pesos determinados pela metodologia do controle sintético conseguiu gerar uma média pré-tratamento para a produção de veículos muito próxima à média verdadeira. $\mathrm{O}$ mesmo vale para o investimento estrangeiro direto, para as despesas do governo, as participações da 
agricultura e da indústria no PIB e para a taxa de participação da força de trabalho. Contudo, para as demais variáveis o ajuste foi menos preciso.

Tabela 2: Países-controle e sua participação na construção da unidade sintética do Brasil

\begin{tabular}{lcclc}
\hline $\begin{array}{l}\text { Unidades de } \\
\text { Controle }\end{array}$ & $\begin{array}{c}\text { Peso ótimo } \\
\text { estimado }\end{array}$ & & $\begin{array}{l}\text { Unidades de } \\
\text { Controle }\end{array}$ & $\begin{array}{c}\text { Peso ótimo } \\
\text { estimado }\end{array}$ \\
\cline { 1 - 2 } \cline { 5 - 5 } Argentina & 0,187 & & Japão & 0,001 \\
Austrália & 0,000 & & Coreia do Sul & 0,000 \\
Áustria & 0,000 & & México & 0,000 \\
Bélgica & 0,000 & & Malásia & 0,000 \\
Canadá & 0,000 & & Holanda & 0,000 \\
China & 0,337 & & Polônia & 0,000 \\
República Tcheca & 0,000 & & Portugal & 0,000 \\
Alemanha & 0,000 & & Romênia & 0,000 \\
Egito & 0,000 & & Rússia & 0,000 \\
Espanha & 0,000 & & Sérvia & 0,000 \\
Finlândia & 0,000 & & Eslováquia & 0,000 \\
França & 0,422 & & Eslovênia & 0,000 \\
Reino Unido & 0,000 & & Suécia & 0,000 \\
Hungria & 0,000 & & Tailândia & 0,000 \\
Indonésia & 0,000 & & Turquia & 0,053 \\
India & 0,000 & & Ucrânia & 0,000 \\
Irã & 0,000 & & Estados Unidos & 0,000 \\
Itália & 0,000 & África do Sul & 0,000 \\
\hline
\end{tabular}

Elaboração dos autores.

Na Figura 1, são traçadas as trajetórias da produção de veículos do Brasil e do Brasil sintético. Para que a série sintética seja um bom contrafactual da série verdadeira, é necessário que ela consiga replicar satisfatoriamente a trajetória da variável de interesse até 2013 (quando o programa entra em vigor). A raiz do erro de previsão quadrático médio para esse período é de 0,07 na escala logarítmica. Ou seja, de acordo com esse critério, pode-se afirmar que a série sintética é uma boa previsora da série tratada no período de prétratamento.

Posteriormente a 2013, a trajetória da série sintética fica acima daquela observada para a série tratada, deixando de ser uma boa previsora desta. Esse comportamento sugere que o programa Inovar-Auto possa ter tido impacto negativo sobre a produção de veículos no Brasil. Por um lado, isso pode ser um colateral indesejado do programa, visto que, como discutido na introdução, o setor alvo da política pode ser prejudicado no caso de seus fornecedores nacionais encontrarem dificuldades de ajuste na produção ou, ainda, para produzir componentes que atendam às exigências tecnológicas. Por outro lado, sabese que este é um resultado que deve ser analisado com parcimônia, uma vez que a economia nacional, no período aqui considerado como pós-tratamento, passou por uma das mais severas crises de sua história recente, fenômeno não observado na mesma intensidade nos demais países e que pode afetar o efeito aqui estimado. ${ }^{11}$

\footnotetext{
${ }^{11}$ Entre 2014 e 2017, o PIB brasileiro apresentou queda acumulada de 5,0\%. Na mesma base de comparação, o crescimento do PIB foi de $14,8 \%$ no mundo, de $8,2 \%$ nos países da Área do Euro
} 
Tabela 3: Média das variáveis preditoras no período pré-tratamento para o Brasil e seu sintético

Brasil Tratado Brasil Sintético

Produção de Veículos (ln)

14,70

14,70

PIB per capita (preços constantes)

$12.915,62$

$21.951,55$

PIB (var. \% anual)

3,42

4,72

(pessoas)

Formação Bruta de Capital (\% do PIB)

90.100 .000

19,11

274.000 .000

Investimento Estrangeiro Direto (entrada líquida, \%

3,19

2,87

do PIB)

Inflação (consumidores, \% anual)

Poupança Bruta (\% do PIB)

6,49

15,70

4,16

Exportação de Bens e Serviços (\% do PIB)

12,81

29,50

Importação de Bens e Serviços (\% do PIB)

12,53

25,43

Despesa Total do Governo (\% do PIB)

38,09

Aricultura (VAB, \% do PIB)

Indústria (VAB, \% do PIB)

27,08

Consumo de Energia Elétrica (KWh per capita)

65,99

$4.391,43$

Taxa de Participação da Força de Trabalho (\%)

62,46

Elaboração dos autores. 
Figura 1: Trajetória da produção de veículos do Brasil e do Brasil Sintético (escala logarítmica)

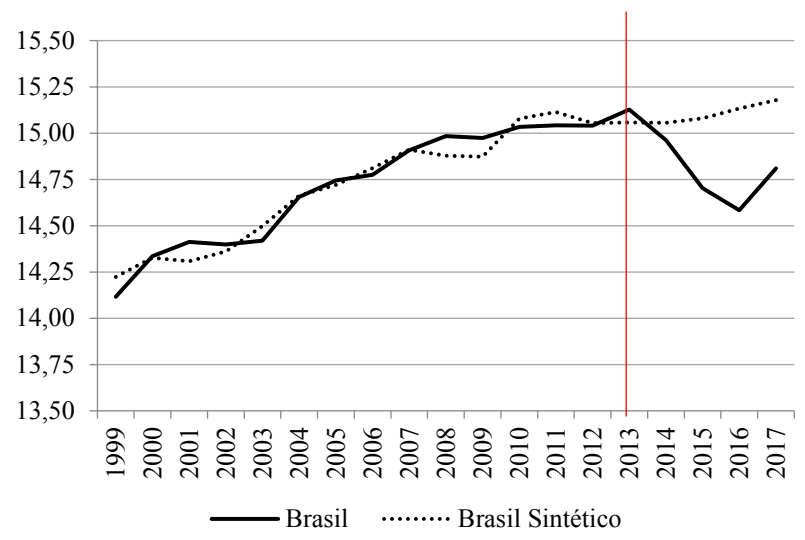

Elaboração dos autores.

Com os resultados obtidos na Figura 1, é possível mensurar o efeito ano a ano, conforme demonstrado na Figura 2. Em 2013, primeiro ano do programa e em um cenário predecessor da severa crise econômica (neste ano, o PIB brasileiro apresentou crescimento de 3\%), o efeito foi positivo em 6,9\%. A partir de então, o impacto mensurado torna-se negativo, aumentando sua magnitude com o passar dos anos até 2016, quando atinge a dimensão de quase $-55 \%$. Em 2017, embora ainda negativo, é menos severo (cerca de $-37 \%$ ). É preciso ressaltar que nos anos de 2014, 2015 e 2016, o PIB brasileiro apresentou variações de $0,5 \%,-3,55 \%$ e $-3,31 \%$, respectivamente, acumulando uma queda de 6,28\% no período. Em 2017, a economia cresceu 1,06\%, revertendo apenas parcialmente a retração observada nos anos anteriores. Assim, é possível que, na ausência da crise, os efeitos do programa possam ser menos negativos ou até mesmo neutros.

Uma forma de testar a robustez do impacto observado é a realização do teste de distribuição dos placebos. Este consiste na construção da série de produção de veículos sintética para todos os 36 países que foram utilizados para a estimação do Brasil sintético, utilizando o mesmo período pré-tratamento (1999 a 2012). Isso feito, calcula-se a diferença das trajetórias observadas de produção de veículos para cada país e sua trajetória sintética. O passo final é a plotagem dessas diferenças em um único gráfico, juntamente com a diferença observada para o Brasil. A ideia é observar se a diferença para o Brasil (país no qual o programa foi implementado) apresenta comportamento distinto em relação às diferenças dos demais países (que não tiveram o programa). Se o efeito encontrado no Brasil não estiver em uma das extremidades da distribuição dos placebos, então conclui-se que o impacto do Inovar-Auto não foi robusto.

Seguindo a recomendação de Abadie et al. (2010), foram utilizados no teste de distribuição dos placebos apenas os países que tiveram um ajuste medido

e naqueles que compõem o G7, de 11,4\% nos demais países desenvolvidos (excluso Área do Euro e G7), de 29,9\% nos países em desenvolvimento da Ásia, de 9,1\% nos países em desenvolvimento da Europa, de 2,5\% na América Latina e de 13,6\% nos países do Oriente Médio, Ásia Central e África Subsaariana (IMF 2020). 
Figura 2: Efeito do programa sobre a produção de veículos

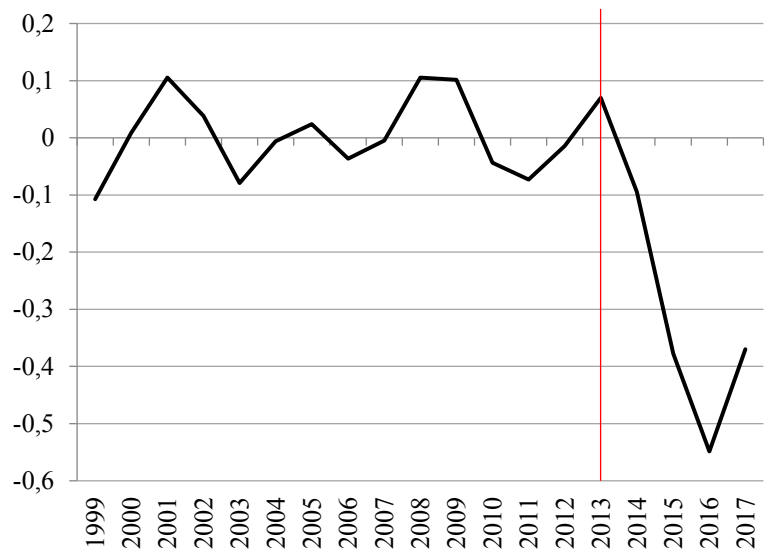

Elaboração dos autores.

Figura 3: Distribuição das diferenças entre os tratados e sintéticos - linha escura $=$ Brasil

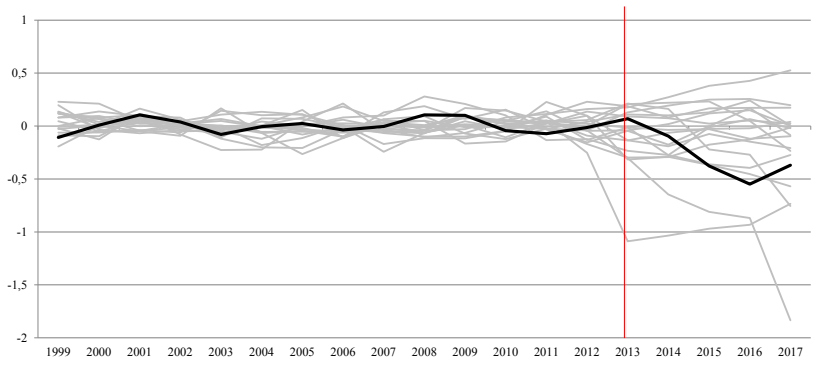

Elaboração dos autores.

pela Raiz do Erro de Previsão Quadrático Médio (REPQM) para o período anterior ao programa não muito superior ao observado para a unidade tratada. Dessa forma, a Figura 3 apresenta essa distribuição apenas com os países cuja medida REPQM pré-programa não foi superior a duas vezes o valor do Brasil. Dos 36 placebos, foram mantidos 18 . O valor das REPQM pré-programa para cada país, bem como a lista daqueles mantidos e excluídos no teste de distribuição dos placebos podem ser observados no Quadro (a) da Tabela A.1 (Anexo). Em todo o período pós-programa, a série da diferença entre o observado e o sintético do Brasil se confunde com as diferenças entre os tratados e sintéticos de outros países, mesmo quando a diferença negativa aumenta de magnitude. Esse teste visual sinaliza, portanto, que não houve efeito robusto do Inovar-Auto sobre a produção de veículos no Brasil.

Por fim, uma forma adicional de avaliar a diferença entre a trajetória observada e sintética do Brasil em relação a essa diferença para os demais países é analisar a distribuição da razão do erro quadrático médio pós-tratamento/prétratamento. A ideia é que se o programa teve efeito sobre a produção de veículos no Brasil, a REPQM do período pós-tratamento será muito maior em relação a REPQM pré-tratamento. Além disso, caso o comportamento observado para o Brasil seja derivado do impacto do programa, o mesmo comportamento 
não deve ser registrado para nas demais localidades. Assim, a razão entre as duas no Brasil deve ser mais elevada em relação a essa razão nos países não afetados. Conforme destaca Abadie et al. (2010), a vantagem dessa avaliação em relação à anterior é que exime o pesquisador da escolha arbitrária dos países que devem ou não ser inseridos no teste de placebo. A Figura 4 mostra essa distribuição para o Brasil e para os 36 países de controle. No Brasil, a razão da REPQM pós/pré-programa foi de 5,22, não sendo a maior observada para todos os países: outros cinco tiveram a razão igual ou superior a esta. Novamente, não é possível certificar a robustez do impacto estimado.

Figura 4: Razão do erro quadrático médio pós-tratamento/prétratamento - Brasil e 36 países-controle (valor arredondado)

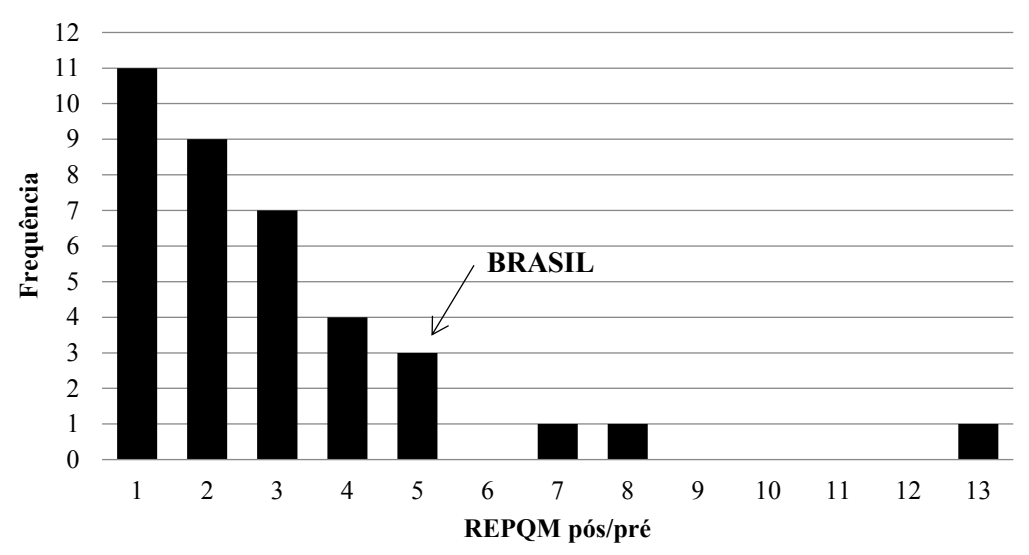

Elaboração dos autores.

Conforme discutido na seção 3, para avaliar a robustez dos resultados obtidos, optou-se por estimar uma segunda versão do modelo de controle sintético. Esta consiste em não utilizar nenhuma covariada como preditora, apenas as defasagens - para todo o período pré-tratamento - da variável de interesse. $\mathrm{Na}$ Tabela 4, é possível observar mudanças na composição e nos pesos atribuídos a cada um dos 36 países candidatos a controle. Nessa abordagem, um número maior de países recebeu ponderação maior que zero na construção da unidade sintética do Brasil. São estes: China (16,6\%), República Tcheca $(7,6 \%)$, Alemanha $(28,8 \%)$, Finlândia $(1,7 \%)$, Irã $(10 \%)$, Indonésia $(8,3 \%)$, Japão $(14,7 \%)$ e Polônia (12,3\%).

As trajetórias da produção de veículos do Brasil e do Brasil sintético podem ser observadas na Figura 5. A REPQM para o período pré-tratamento 0,036 na escala logarítmica. Dessa forma, registra-se que, desconsiderando as covariadas e utilizando apenas as defasagens da variável de interesse como preditoras, o ajuste do modelo se mostra melhor. Assim como no caso anterior, no período pós-programa, a trajetória da série sintética fica acima daquela observada para a série tratada, corroborando o resultado previamente encontrado, de que o programa Inovar-Auto possa ter tido impacto negativo sobre a produção de veículos no Brasil.

$\mathrm{Na}$ análise da diferença ano a ano entre a série observada e a sintética (Figura 6), é possível observar comportamento semelhante ao registrado anteriormente, embora em magnitudes levemente mais expressivas. Em 2013, 
Tabela 4: Países-controle e sua participação na construção da unidade sintética do Brasil - variável dependente defasada utilizada como preditora

\begin{tabular}{lcllr}
\hline $\begin{array}{l}\text { Unidades de } \\
\text { Controle }\end{array}$ & $\begin{array}{c}\text { Peso ótimo } \\
\text { estimado }\end{array}$ & & $\begin{array}{l}\text { Unidades de } \\
\text { Controle }\end{array}$ & $\begin{array}{c}\text { Peso ótimo } \\
\text { estimado }\end{array}$ \\
\cline { 1 - 2 } \cline { 5 - 5 } Argentina & 0,000 & & Japão & 0,147 \\
Austrália & 0,000 & & Coreia do Sul & 0,000 \\
Áustria & 0,000 & & México & 0,000 \\
Bélgica & 0,000 & & Malásia & 0,000 \\
Canadá & 0,000 & & Holanda & 0,000 \\
China & 0,166 & & Polônia & 0,123 \\
República Tcheca & 0,076 & & Portugal & 0,000 \\
Alemanha & 0,288 & & Romênia & 0,000 \\
Egito & 0,000 & & Rússia & 0,000 \\
Espanha & 0,000 & & Sérvia & 0,000 \\
Finlândia & 0,017 & & Eslováquia & 0,000 \\
França & 0,000 & & Eslovênia & 0,000 \\
Reino Unido & 0,000 & & Suécia & 0,000 \\
Hungria & 0,000 & & Tailândia & 0,000 \\
Indonésia & 0,083 & & Turquia & 0,000 \\
Índia & 0,000 & & Ucrânia & 0,000 \\
Irã & 0,100 & & Estados Unidos & 0,000 \\
Itália & 0,000 & & África do Sul & 0,000 \\
\hline
\end{tabular}

Elaboração dos autores.

primeiro ano do programa, é computada uma diferença de $11,5 \%$ na produção de veículos. A partir de então, a diferença para a ser negativa, nas grandezas de $-15,7 \%,-41,8 \%,-58,6 \%$ e $-39,6 \%$ nos anos de 2014, 2015, 2016 e 2017, respectivamente.

O teste de distribuição dos placebos foi desenvolvido com base nos mesmos critérios descritos para o modelo anterior. Nessa especificação, o número de países inseridos no teste é menor, o que era esperado devido ao melhor ajuste da produção de veículos entre o Brasil observado e o sintético no período pré-programa. Assim, depois de excluir os países cuja REPQM é mais de duas vezes superior à observada para o caso brasileiro, remanesceram no teste apenas doze. O valor das REPQM pré-programa para cada país, bem como a lista daqueles mantidos e excluídos no teste de distribuição dos placebos podem ser observados no Quadro (b) da Tabela A.1 (Anexo). Apesar do melhor ajuste desse modelo, na da Figura 7 nota-se que a série da diferença entre o observado e o sintético do Brasil não pertence às extremidades da distribuição no período pós-tratamento. Assim, essa especificação corrobora a ausência de robustez do impacto estimado, já registrado na estimação que utiliza diversas covariadas como preditoras.

Para validação da ausência de robustez do efeito encontrado, também foi realizada para essa abordagem a construção da distribuição da razão do erro quadrático médio pós-tratamento/pré-tratamento para os 36 países candidatos a controle. O resultado pode ser observado na Figura 8. Embora a razão tenha aumentado para o Brasil na comparação com o modelo anterior (tendo passado de 5,22 para 10,5 ), a razão máxima observada no conjunto dos países também se elevou (de 12,6 para 19). É possível ver que outros três países tiveram a razão superior à brasileira, não sendo possível afirmar, portanto, que o impacto registrado é robusto. 
Figura 5: Trajetória da produção de veículos do Brasil e do Brasil Sintético (escala logarítmica) - variável dependente defasada utilizada como preditora

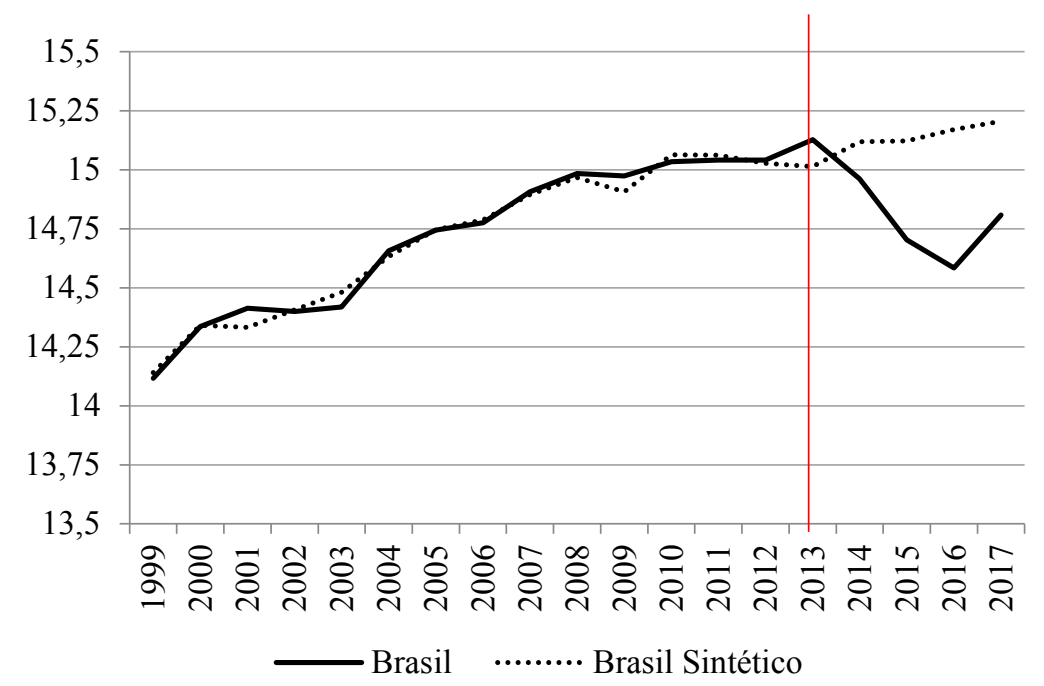

Elaboração dos autores.

Figura 6: Efeito do programa sobre a produção de veículos - variável dependente defasada utilizada como preditora

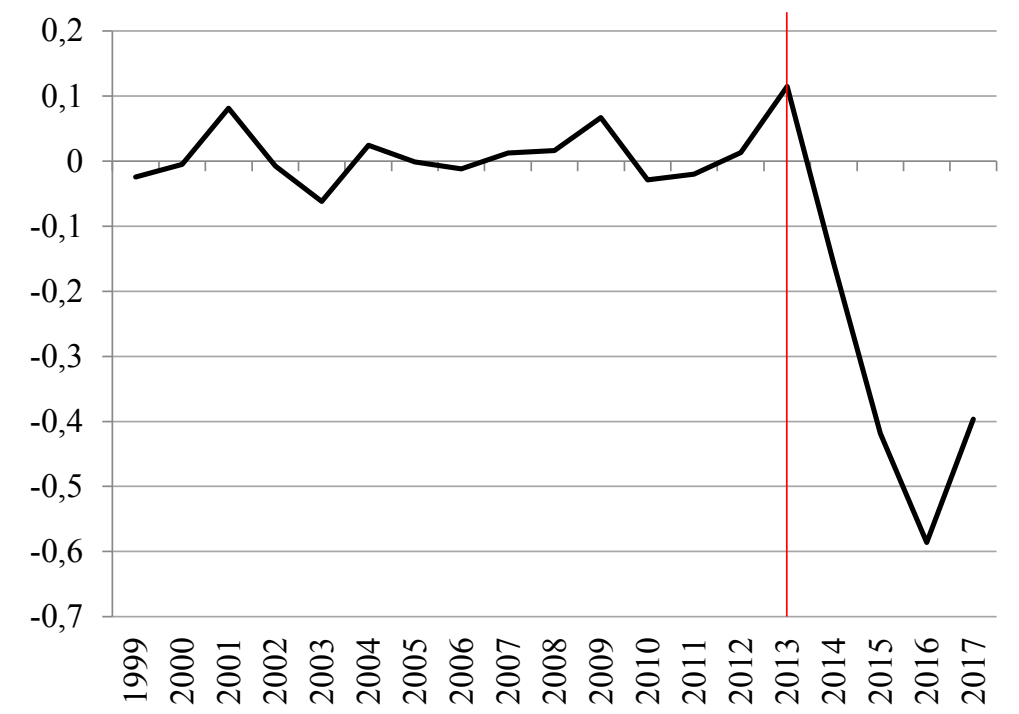

Elaboração dos autores. 
Figura 7: Distribuição das diferenças entre os tratados e sintéticos - linha escura $=$ Brasil - variável dependente defasada utilizada como preditora

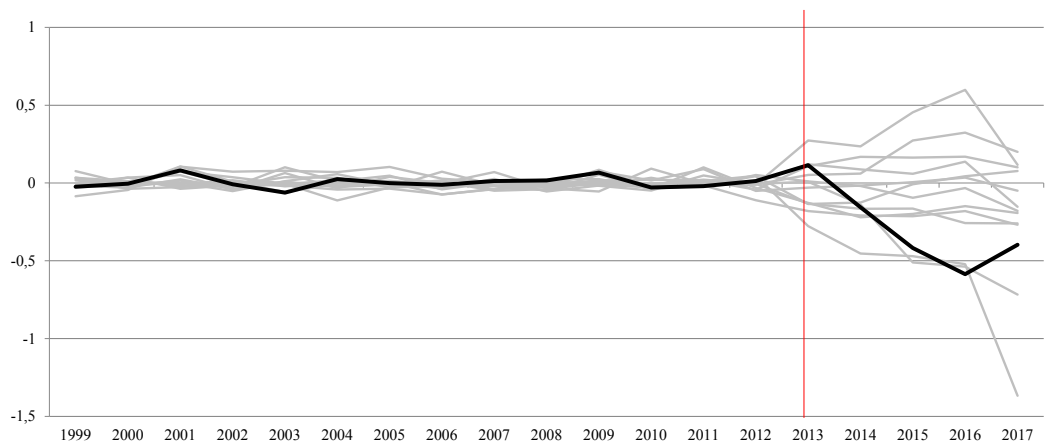

Elaboração dos autores.

Figura 8: Razão do erro quadrático médio pós-tratamento/prétratamento - Brasil e 36 países-controle (valor arredondado) - variável dependente defasada utilizada como preditora

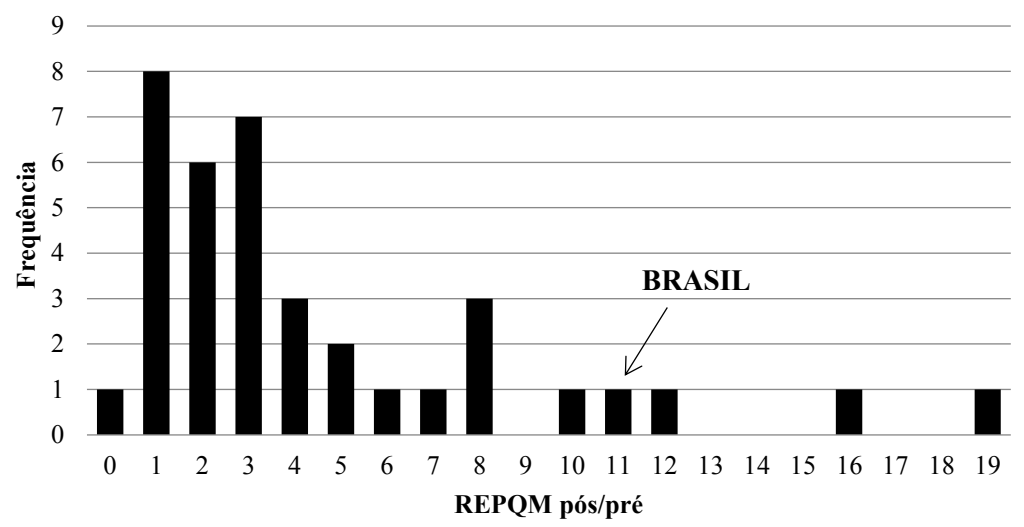

Elaboração dos autores.

\subsection{Resultados do Modelo de Controle Sintético para a Comparação entre Setores (Nacional)}

Como já mencionado, o modelo de controle sintético também foi estimado a partir de uma base de dados nacionais, que contempla as informações dos setores da indústria de transformação brasileira. Aqui, foi considerado como afetado pela política (tratado) o setor de fabricação de veículos automotores e como candidatos a controle os demais 23 setores da indústria de transformação. Foram investigados os impactos do programa Inovar-Auto sobre quatro variáveis: pessoal ocupado, custo das operações industriais, ativo imobilizado e valor adicionado bruto. Para cada uma das variáveis de interesse, foi estimado um modelo. A Tabela 5 reporta os pesos atribuídos para cada um dos 23 setores candidatos a controle na construção do setor de veículos sintético.

Nos quatro modelos, o setor de veículos sintético foi estimado a partir de outros três segmentos da indústria de transformação, divergindo quanto ao peso e à composição em cada um deles. Quando da investigação do efeito 
Tabela 5: Setores-controle e sua participação na construção de cada unidade sintética

\begin{tabular}{|c|c|c|c|c|}
\hline \multirow[b]{2}{*}{ Unidades de Controle } & \multicolumn{4}{|c|}{ Peso ótimo estimado para cada variável de resultado } \\
\hline & $\begin{array}{l}\text { Pessoal } \\
\text { Ocupado } \\
\text { em } 31 / 12\end{array}$ & $\begin{array}{l}\text { Custo das } \\
\text { Operações } \\
\text { Industriais }\end{array}$ & $\begin{array}{l}\text { Ativo Imobilizado } \\
\text { (Aquisições e } \\
\text { Melhorias) }\end{array}$ & $\begin{array}{l}\text { Valor } \\
\text { Adicionado } \\
\text { Bruto }\end{array}$ \\
\hline $\begin{array}{l}\text { Fabricação de produtos alimen- } \\
\text { tícios }\end{array}$ & 0,329 & 0,310 & 0,396 & 0,274 \\
\hline Fabricação de bebidas & 0,000 & 0,000 & 0,000 & 0,000 \\
\hline Fabricação de produtos do fumo & 0,000 & 0,000 & 0,000 & 0,000 \\
\hline Fabricação de produtos têxteis & 0,000 & 0,000 & 0,000 & 0,000 \\
\hline $\begin{array}{l}\text { Confecção de artigos do vestuá- } \\
\text { rio e acessórios }\end{array}$ & 0,000 & 0,000 & 0,000 & 0,000 \\
\hline $\begin{array}{l}\text { Preparação de couros e fabrica- } \\
\text { ção de artefatos de couro, arti- } \\
\text { gos para viagem e calçados }\end{array}$ & 0,000 & 0,000 & 0,000 & 0,000 \\
\hline $\begin{array}{l}\text { Fabricação de produtos de ma- } \\
\text { deira }\end{array}$ & 0,000 & 0,000 & 0,000 & 0,000 \\
\hline $\begin{array}{l}\text { Fabricação de celulose, papel e } \\
\text { produtos de papel }\end{array}$ & 0,000 & 0,000 & 0,000 & 0,000 \\
\hline $\begin{array}{l}\text { Impressão e reprodução de gra- } \\
\text { vações }\end{array}$ & 0,000 & 0,000 & 0,000 & 0,000 \\
\hline $\begin{array}{l}\text { Fabricação de coque, de produ- } \\
\text { tos derivados do petróleo e de bi- } \\
\text { ocombustíveis }\end{array}$ & 0,000 & 0,028 & 0,000 & 0,397 \\
\hline $\begin{array}{l}\text { Fabricação de produtos quími- } \\
\text { cos }\end{array}$ & 0,577 & 0,662 & 0,319 & 0,328 \\
\hline $\begin{array}{l}\text { Fabricação de produtos far- } \\
\text { moquímicos e farmacêuticos }\end{array}$ & 0,000 & 0,000 & 0,000 & 0,000 \\
\hline $\begin{array}{l}\text { Fabricação de produtos de borra- } \\
\text { cha e de material plástico }\end{array}$ & 0,000 & 0,000 & 0,000 & 0,000 \\
\hline $\begin{array}{l}\text { Fabricação de produtos de mine- } \\
\text { rais não metálicos }\end{array}$ & 0,000 & 0,000 & 0,000 & 0,000 \\
\hline Metalurgia & 0,000 & 0,000 & 0,000 & 0,000 \\
\hline $\begin{array}{l}\text { Fabricação de produtos de me- } \\
\text { tal, exceto máquinas e equipa- } \\
\text { mentos }\end{array}$ & 0,000 & 0,000 & 0,000 & 0,000 \\
\hline $\begin{array}{l}\text { Fabricação de equipamentos de } \\
\text { informática, produtos eletrôni- } \\
\text { cos e ópticos }\end{array}$ & 0,000 & 0,000 & 0,000 & 0,000 \\
\hline $\begin{array}{l}\text { Fabricação de máquinas, apare- } \\
\text { lhos e materiais elétricos }\end{array}$ & 0,000 & 0,000 & 0,000 & 0,000 \\
\hline $\begin{array}{l}\text { Fabricação de máquinas e equi- } \\
\text { pamentos }\end{array}$ & 0,094 & 0,000 & 0,285 & 0,000 \\
\hline $\begin{array}{l}\text { Fabricação de outros equipa- } \\
\text { mentos de transporte, exceto veí- } \\
\text { culos automotores }\end{array}$ & 0,000 & 0,000 & 0,000 & 0,000 \\
\hline Fabricação de móveis & 0,000 & 0,000 & 0,000 & 0,000 \\
\hline Fabricação de produtos diversos & 0,000 & 0,000 & 0,000 & 0,000 \\
\hline $\begin{array}{l}\text { Manutenção, reparação e insta- } \\
\text { lação de máquinas e equipamen- } \\
\text { tos }\end{array}$ & 0,000 & 0,000 & 0,000 & 0,000 \\
\hline
\end{tabular}

Elaboração dos autores. 
do programa sobre o pessoal ocupado, os setores foram produtos alimentícios $(32,9 \%)$, produtos químicos $(57,7 \%)$ e máquinas e equipamentos $(9,4 \%)$. Quando foi mensurado o impacto sobre o custo das operações industriais, o setor de veículos sintético foi formado a partir das indústrias de produtos alimentícios (31\%), fabricação de coque, de produtos derivados do petróleo e de biocombustíveis $(2,8 \%)$ e produtos químicos $(66,2 \%)$. Por sua vez, na estimação do impacto sobre os ativos imobilizados, ganharam peso os setores de produtos alimentícios $(39,6 \%)$, produtos químicos $(31,9 \%)$ e máquinas e equipamentos $(28,5 \%)$. Por fim, quando a variável de interesse foi o valor adicionado bruto, as indústrias que formaram a unidade sintética foram as de produtos alimentícios $(27,4 \%)$, fabricação de coque, de produtos derivados do petróleo e de biocombustíveis $(39,7 \%)$ e produtos químicos $(32,8 \%)$.

Como visto, o setor de produtos alimentícios e o de produtos químicos estiveram presentes nos quatro modelos estimados. Ainda, os segmentos que compuseram o setor de veículos sintéticos foram os mesmos para a investigação do impacto sobre o pessoal ocupado e o ativo imobilizado. Também se observou a mesma composição no caso da análise do efeito sobre os custos e o valor adicionado bruto.

Em cada um dos modelos, foram consideradas como covariadas as quatro variáveis de interesse e também o número de empresas no agregado do setor. A Tabela 6 traz as médias para o período de pré-tratamento dessas variáveis no setor de veículo e seus sintéticos. Assim, na primeira coluna são apresentadas as médias observadas do setor tratado e nas colunas subsequentes as médias dos setores sintéticos para cada uma das variáveis investigadas.

É possível ver que, com exceção do número de empresas, a estimação foi capaz de gerar uma média pré-tratamento para as covariadas muito próxima às médias verdadeiras. Apenas no caso do setor de veículos sintético para aferição de efeito sobre o valor adicionado bruto os valores são um pouco mais divergentes em relação ao observado na unidade tratada.

Tabela 6: Média das variáveis preditoras no período pré-tratamento para o setor de veículos (tratado) e suas unidades sintéticas (escala logarítmica)

\begin{tabular}{|c|c|c|c|c|c|}
\hline \multirow[b]{2}{*}{ Variáveis Preditoras } & \multirow[b]{2}{*}{ Tratado } & \multicolumn{4}{|c|}{ SINTÉTICO } \\
\hline & & $\begin{array}{c}\text { Pessoal } \\
\text { Ocupado } \\
\text { em 31/12 }\end{array}$ & $\begin{array}{l}\text { Custo das } \\
\text { Operações } \\
\text { Industriais }\end{array}$ & $\begin{array}{c}\text { Ativo Imob. } \\
\text { Aquis. e } \\
\text { Melh.) }\end{array}$ & $\begin{array}{l}\text { Valor } \\
\text { Adic. } \\
\text { Bruto }\end{array}$ \\
\hline Pessoal Ocupado em 31/12 & 13,13 & 13,13 & 13,06 & 13,31 & 12,83 \\
\hline $\begin{array}{l}\text { Custo das Operações Indus- } \\
\text { triais }\end{array}$ & 18,65 & 18,61 & 18,65 & 18,49 & 18,35 \\
\hline $\begin{array}{l}\text { Ativo Imobilizado (Aquisi- } \\
\text { çôes e Melhorias) }\end{array}$ & 16,01 & 16,13 & 16,24 & 16,02 & 16,79 \\
\hline Valor Adicionado Bruto & 17,79 & 17,57 & 17,60 & 17,56 & 17,77 \\
\hline Número de Empresas & 3.742 & 10.691 & 9.918 & 12.489 & 7.645 \\
\hline
\end{tabular}

Elaboração dos autores.

Na Figura 9 é possível comparar a trajetória do setor de veículos e seus sintéticos. Os ajustes foram melhores na investigação do impacto sobre o pessoal ocupado, o custo e o valor adicionado, cujas REPQM para o período prétratamento foram de 0,018, 0,071 e 0,038 na escala logarítmica. Já no modelo que buscou mensurar o efeito sobre os ativos imobilizados, a REPQM foi mais elevada, de 0,195. O descolamento das trajetórias observada e sintética para 
esse caso fica evidente no Quadro (c).

A estimação aponta para impacto negativo no pessoal ocupado, no custo das operações industriais e no valor adicionado bruto. No primeiro e no terceiro caso, se robustos, são efeitos não desejados do programa. Por sua vez, o impacto estimado é positivo sobre o ativo imobilizado, o que seria um resultado desejado.

Figura 9: Trajetória das variáveis de interesse no setor de veículos e sua contrapartida sintética (escala logarítmica)
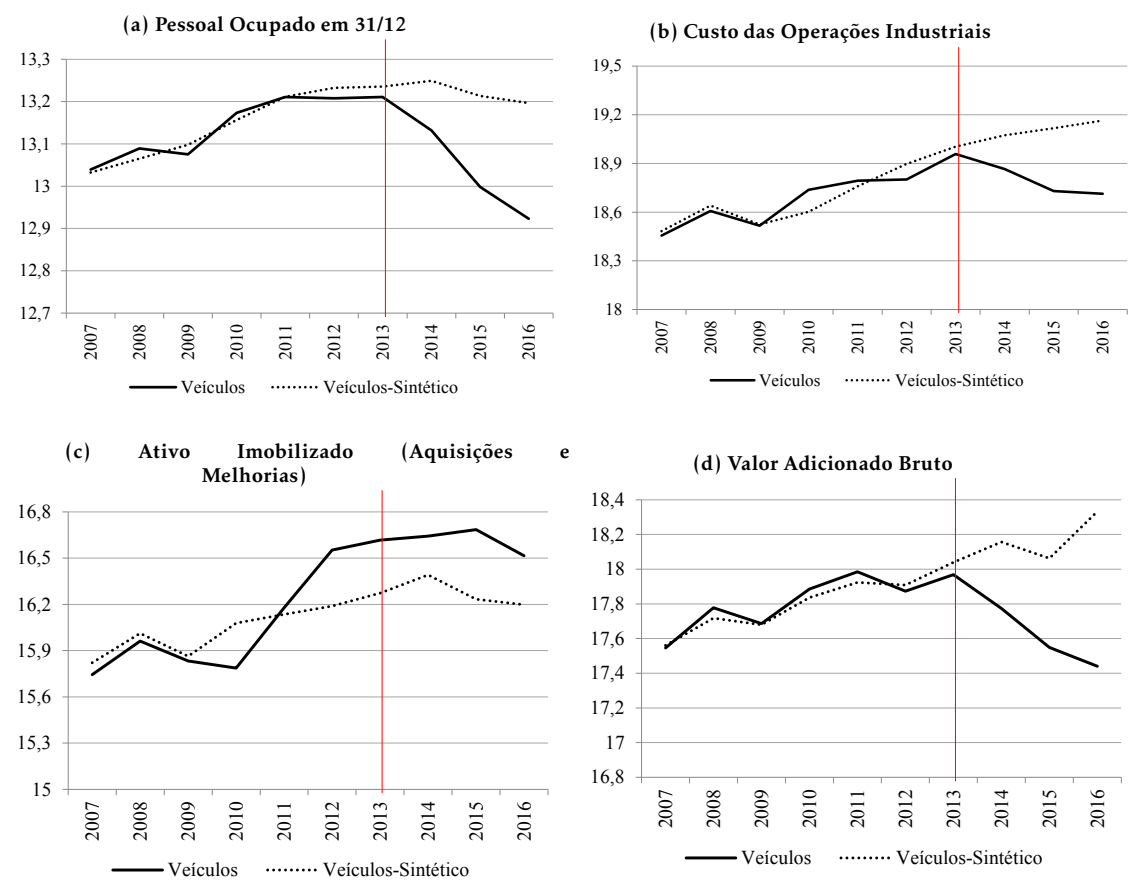

Elaboração dos autores.

A Tabela 7 traz a magnitude do efeito, ano a ano, para cada uma das especificações estimadas. Adicionalmente, é feita a inferência dos resultados, conforme estratégia proposta por Cavallo et al. (2013), que generaliza a ideia dos testes de placebos propostas por Abadie et al. (2010). Em linhas gerais, o método de inferência examina se o efeito estimado para o setor afetado pelo programa é grande em relação à distribuição dos efeitos estimados para os setores não afetados. Calcula-se então um nível de significância específico (p-valor) para o impacto estimado. De maneira mais específica, o método de controle sintético é aplicado a todos os setores que são potenciais controles na amostra. Isso permite verificar se o efeito estimado pelo método para o setor que foi afetado pelo programa é maior em relação ao efeito estimado para um setor escolhido aleatoriamente - e que não tenha sido afetado pelo programa. ${ }^{12}$ É possível ver que nos casos do custo das operações industriais e do ativo imobilizado os efeitos estimados não são significativos para nenhum dos anos pós-programa. Já os efeitos negativos, e não desejados, sobre o pes-

\footnotetext{
${ }^{12}$ Para maior detalhamento do procedimento de inferência e formalização, ver Cavallo et al. (2013).
} 
soal ocupado e o valor adicionado bruto se mostraram significativos a partir do terceiro e segundo anos, respectivamente.

Para essa especificação, também foi desenvolvido o teste de distribuição dos placebos, com vistas a validar os resultados apresentados na Tabela 7. $\mathrm{O}$ critério adotado aqui foi o mesmo empregado na estimação do modelo de controle sintético com dados de países, analisado na subseção 4.1. Assim, foram retirados do teste todos os setores cuja REPQM para o período pré-tratamento foi mais de duas vezes superior àquela registrada para o setor de veículos.

Após esse procedimento, remanesceram no teste: para o modelo que estima o impacto sobre o pessoal ocupado, cinco setores; para o custo das operações industriais, 21; para o ativo imobilizado, 20; e para o valor adicionado bruto, 9. O valor dos REPQM pré-programa para cada modelo e setor, bem como a lista daqueles mantidos e excluídos no teste de distribuição dos placebos, podem ser observados na Tabela A.2 (Anexo).

Na da Figura 10, é possível ver que, de fato, nos casos dos efeitos sobre o custo e o ativo, a série da diferença entre o observado e o sintético do setor de veículos se mistura às dos placebos no período pós-tratamento. Por sua vez, nos casos dos impactos sobre o pessoal ocupado e o valor adicionado bruto, a série parece pertencer à extremidade da distribuição, ao menos para os últimos anos do período pós-tratamento.

Tal qual na estimação do modelo de controle sintético com dados internacionais, na presente abordagem também foi estimada uma segunda versão do modelo, na qual nenhuma covariada foi utilizada como preditora, apenas as defasagens - para todo o período pré-tratamento - da variável de interesse. Os resultados são apresentados no texto que segue.

A Tabela 8 traz o peso atribuído a cada segmento da indústria de transformação na construção do setor de veículos sintético, para cada um dos quatro modelos estimados. É possível notar que, exceto no caso da variável de interesse custo das operações industriais, o número de setores que ganhou ponderação na criação da unidade sintética aumentou.

Para a estimação do impacto sobre o pessoal ocupado, seis segmentos formaram o setor de veículos sintético: fabricação de produtos alimentícios $(20,9 \%)$; confecção de artigos do vestuário e acessórios $(11,3 \%)$; preparação de couros e fabricação de artefatos de couro, artigos para viagem e calçados $(8,7 \%)$; metalurgia (16,4\%); fabricação de máquinas e equipamentos $(41,9 \%)$; e manutenção, reparação e instalação de máquinas e equipamentos $(0,8 \%)$. Os três setores que formaram a unidade sintética para a investigação do efeito sobre o custo das operações industriais foram: fabricação de produtos alimentícios (55,5\%); metalurgia $(41,2 \%)$; e fabricação de máquinas, aparelhos e materiais elétricos $(3,3 \%)$. No caso da análise sobre o ativo imobilizado, os cinco setores que ganharam peso maior que zero foram: fabricação de produtos alimentícios (40,6\%); fabricação de celulose, papel e produtos de papel $(0,9 \%)$; fabricação de coque, de produtos derivados do petróleo e de biocombustíveis $(3,2 \%)$; fabricação de produtos de borracha e de material plástico $(17,6 \%)$; e fabricação de produtos de minerais não metálicos $(37,6 \%)$. Por fim, para a investigação dos impactos sobre o valor adicionado bruto, os quatro setores que compuseram a unidade sintética foram: fabricação de produtos alimentícios (26,4\%); fabricação de coque, de produtos derivados do petróleo e de biocombustíveis $(50,3 \%)$; metalurgia $(2,8 \%)$; e fabricação de máquinas e equipamentos $(20,5 \%)$. 
Tabela 7: Efeito estimado do programa sobre as variáveis de interesse (por ano) e p-valor

\begin{tabular}{|c|c|c|c|c|}
\hline & \multicolumn{2}{|c|}{ Pessoal Ocupado em 31/12 } & \multicolumn{2}{|c|}{ Custo das Operações Industriais } \\
\hline & Efeito & p-valor & Efeito & p-valor \\
\hline$\overline{2013}$ & $-0,02$ & 0,78 & $-0,04$ & 0,52 \\
\hline 2014 & $-0,12$ & 0,30 & $-0,21$ & 0,13 \\
\hline 2015 & $-0,22$ & 0,09 & $-0,39$ & 0,13 \\
\hline \multirow[t]{3}{*}{2016} & $-0,27$ & 0,09 & $-0,45$ & 0,13 \\
\hline & \multicolumn{2}{|c|}{ Ativo Imobilizado (Aquis. e Melhorias) } & \multicolumn{2}{|c|}{ Valor Adicionado Bruto } \\
\hline & Efeito & p-valor & Efeito & p-valor \\
\hline 2013 & 0,34 & 0,39 & $-0,07$ & 0,57 \\
\hline 2014 & 0,25 & 0,43 & $-0,38$ & 0,00 \\
\hline 2015 & 0,45 & 0,30 & $-0,51$ & 0,09 \\
\hline 2016 & 0,32 & 0,43 & $-0,89$ & 0,00 \\
\hline
\end{tabular}

Elaboração dos autores. 
Figura 10: Distribuição das diferenças entre os tratados e sintéticos - linha escura $=$ veículos

(a) Pessoal Ocupado em 31/12

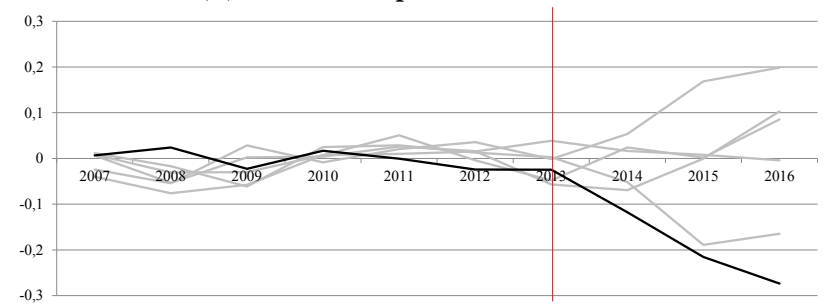

(b) Custo das Operações Industriais

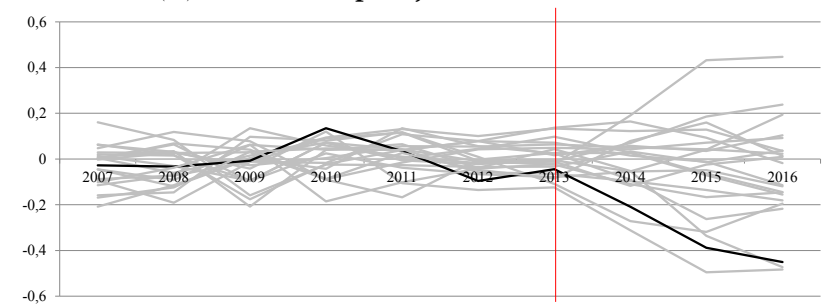

(c) Ativo Imobilizado (Aquisições e Melhorias)

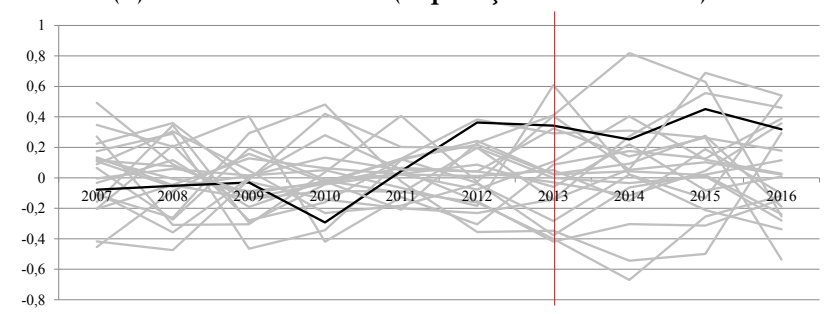

(d) Valor Adicionado Bruto

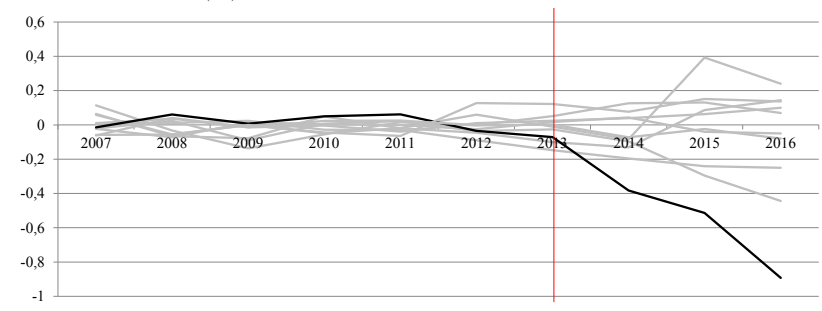

Elaboração dos autores. 
Tabela 8: Setores-controle e sua participação na construção de cada unidade sintética - variável de interesse defasada utilizada como preditora

\begin{tabular}{|c|c|c|c|c|}
\hline \multirow[b]{2}{*}{ Unidades de Controle } & \multicolumn{4}{|c|}{ Peso ótimo estimado para cada variável de resultado } \\
\hline & $\begin{array}{l}\text { Pessoal } \\
\text { Ocupado } \\
\text { em } 31 / 12\end{array}$ & $\begin{array}{l}\text { Custo das } \\
\text { Operações } \\
\text { Industriais }\end{array}$ & $\begin{array}{l}\text { Ativo Imobilizado } \\
\text { (Aquisições e } \\
\text { Melhorias) }\end{array}$ & $\begin{array}{c}\text { Valor } \\
\text { Adicionado } \\
\text { Bruto }\end{array}$ \\
\hline $\begin{array}{l}\text { Fabricação de produtos alimen- } \\
\text { tícios }\end{array}$ & 0,209 & 0,555 & 0,406 & 0,264 \\
\hline Fabricação de bebidas & 0,000 & 0,000 & 0,000 & 0,000 \\
\hline Fabricação de produtos do fumo & 0,000 & 0,000 & 0,000 & 0,000 \\
\hline Fabricação de produtos têxteis & 0,000 & 0,000 & 0,000 & 0,000 \\
\hline $\begin{array}{l}\text { Confecção de artigos do vestuá- } \\
\text { rio e acessórios }\end{array}$ & 0,113 & 0,000 & 0,000 & 0,000 \\
\hline $\begin{array}{l}\text { Preparação de couros e fabrica- } \\
\text { ção de artefatos de couro, arti- } \\
\text { gos para viagem e calçados }\end{array}$ & 0,087 & 0,000 & 0,000 & 0,000 \\
\hline $\begin{array}{l}\text { Fabricação de produtos de ma- } \\
\text { deira }\end{array}$ & 0,000 & 0,000 & 0,000 & 0,000 \\
\hline $\begin{array}{l}\text { Fabricação de celulose, papel e } \\
\text { produtos de papel }\end{array}$ & 0,000 & 0,000 & 0,009 & 0,000 \\
\hline $\begin{array}{l}\text { Impressão e reprodução de gra- } \\
\text { vações }\end{array}$ & 0,000 & 0,000 & 0,000 & 0,000 \\
\hline $\begin{array}{l}\text { Fabricação de coque, de produ- } \\
\text { tos derivados do petróleo e de bi- } \\
\text { ocombustíveis }\end{array}$ & 0,000 & 0,000 & 0,032 & 0,503 \\
\hline $\begin{array}{l}\text { Fabricação de produtos quími- } \\
\text { cos }\end{array}$ & 0,000 & 0,000 & 0,000 & 0,000 \\
\hline $\begin{array}{l}\text { Fabricação de produtos far- } \\
\text { moquímicos e farmacêuticos }\end{array}$ & 0,000 & 0,000 & 0,000 & 0,000 \\
\hline $\begin{array}{l}\text { Fabricação de produtos de borra- } \\
\text { cha e de material plástico }\end{array}$ & 0,000 & 0,000 & 0,176 & 0,000 \\
\hline $\begin{array}{l}\text { Fabricação de produtos de mine- } \\
\text { rais não metálicos }\end{array}$ & 0,000 & 0,000 & 0,376 & 0,000 \\
\hline Metalurgia & 0,164 & 0,412 & 0,000 & 0,028 \\
\hline $\begin{array}{l}\text { Fabricação de produtos de me- } \\
\text { tal, exceto máquinas e equipa- } \\
\text { mentos }\end{array}$ & 0,000 & 0,000 & 0,000 & 0,000 \\
\hline $\begin{array}{l}\text { Fabricação de equipamentos de } \\
\text { informática, produtos eletrôni- } \\
\text { cos e ópticos }\end{array}$ & 0,000 & 0,000 & 0,000 & 0,000 \\
\hline $\begin{array}{l}\text { Fabricação de máquinas, apare- } \\
\text { lhos e materiais elétricos }\end{array}$ & 0,000 & 0,033 & 0,000 & 0,000 \\
\hline $\begin{array}{l}\text { Fabricação de máquinas e equi- } \\
\text { pamentos }\end{array}$ & 0,419 & 0,000 & 0,000 & 0,205 \\
\hline $\begin{array}{l}\text { Fabricação de outros equipa- } \\
\text { mentos de transporte, exceto veí- } \\
\text { culos automotores }\end{array}$ & 0,000 & 0,000 & 0,000 & 0,000 \\
\hline Fabricação de móveis & 0,000 & 0,000 & 0,000 & 0,000 \\
\hline Fabricação de produtos diversos & 0,000 & 0,000 & 0,000 & 0,000 \\
\hline $\begin{array}{l}\text { Manutenção, reparação e insta- } \\
\text { lação de máquinas e equipamen- } \\
\text { tos }\end{array}$ & 0,008 & 0,000 & 0,000 & 0,000 \\
\hline
\end{tabular}

Elaboração dos autores. 
A Figura 11 traz as médias para o período de pré e pós-tratamento das variáveis preditoras (a variável de interesse defasada) no setor de veículo e seus sintéticos. Em todos os casos a estimação foi capaz de gerar uma média prétratamento para as covariadas muito próxima às médias verdadeiras. Com o uso da variável dependente defasada como preditora, os ajustes melhoraram em relação à abordagem anterior, sendo de 0,0007 para o pessoal ocupado, 0,042 para o custo das operações industriais, 0,122 para o ativo imobilizado e 0,026 para o valor adicionado. Pode-se notar que o pior ajuste segue sendo para a investigação do impacto sobre o ativo imobilizado. Assim como no caso interior, observam-se impactos negativos do programa sobre o pessoal ocupado, o custo das operações industriais e o valor adicionado bruto e positivo sobre o ativo imobilizado.

Figura 11: Trajetória das variáveis de interesse no setor de veículos e sua contrapartida sintética (escala logarítmica) - variável de interesse defasada utilizada como preditora
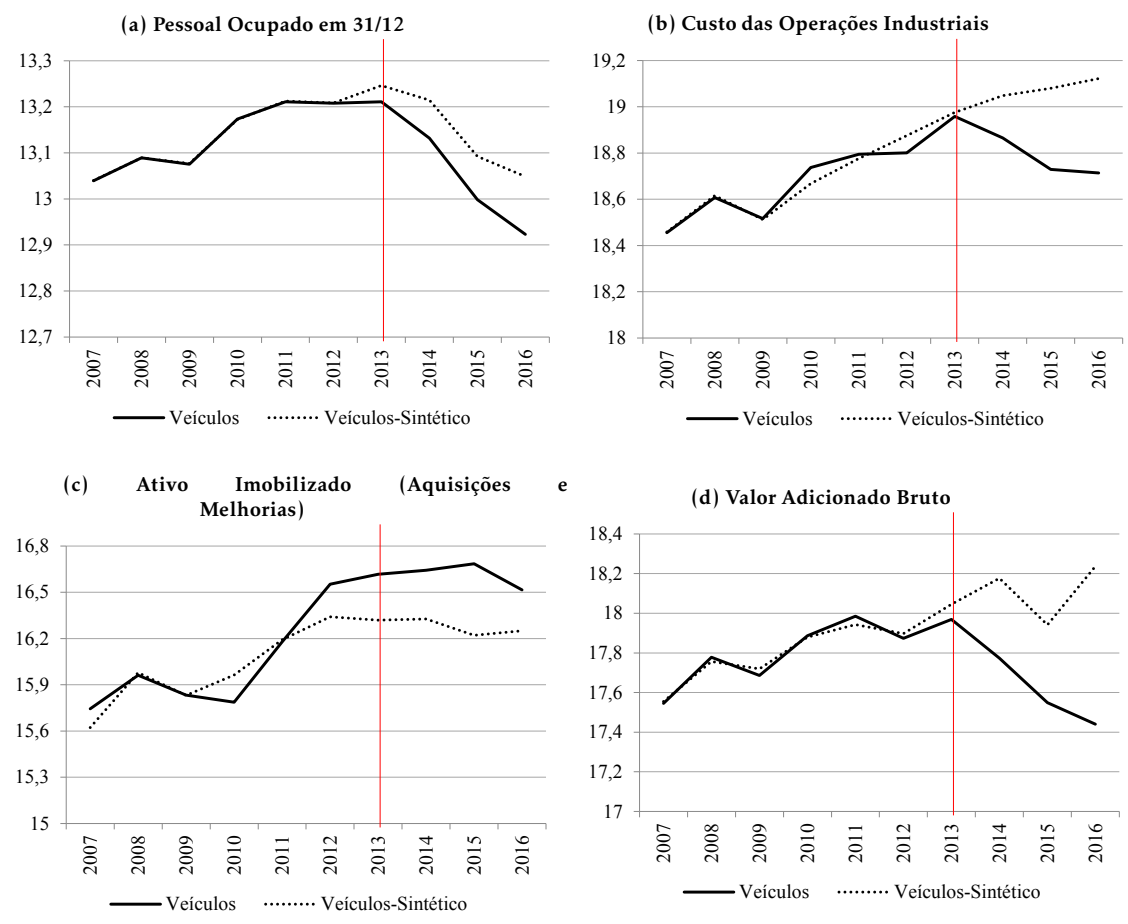

Elaboração dos autores.

Na Tabela 9 é possível ver, para cada ano, a magnitude do efeito em cada um dos modelos estimados, bem como seus níveis de significância. Os resultados são significativos apenas para o efeito sobre o valor adicionado, a partir do segundo ano. Ou seja, as estimações sugerem que o programa não teve impacto sobre as variáveis investigadas.

Por fim, a Figura 12 apresenta o teste de distribuição dos placebos, que corrobora com os resultados da Tabela 8 , ou seja, apenas para a investigação sobre o valor adicionado parece pertencer à extremidade da distribuição, ao menos para os últimos anos do período pós-tratamento. Cabe mencionar que 
Tabela 9: Efeito estimado do programa, por ano - variável de interesse defasada utilizada como preditora

\begin{tabular}{|c|c|c|c|c|}
\hline & \multicolumn{2}{|c|}{ Pessoal Ocupado em 31/12 } & \multicolumn{2}{|c|}{ Custo das Operações Industriais } \\
\hline & Efeito & p-valor & Efeito & p-valor \\
\hline 2013 & $-0,04$ & 0,39 & $-0,02$ & 0,78 \\
\hline 2014 & $-0,08$ & 0,35 & $-0,18$ & 0,26 \\
\hline 2015 & $-0,09$ & 0,43 & $-0,35$ & 0,22 \\
\hline \multirow[t]{3}{*}{2016} & $-0,13$ & 0,48 & $-0,41$ & 0,13 \\
\hline & \multicolumn{2}{|c|}{ Ativo Imobilizado (Aquis. e Melhorias) } & \multicolumn{2}{|c|}{ Valor Adicionado Bruto } \\
\hline & Efeito & p-valor & Efeito & p-valor \\
\hline$\overline{2013}$ & 0,30 & 0,26 & $-0,08$ & $\overline{0,22}$ \\
\hline 2014 & 0,32 & 0,43 & $-0,40$ & 0,00 \\
\hline 2015 & 0,46 & 0,22 & $-0,39$ & 0,09 \\
\hline 2016 & 0,27 & 0,65 & $-0,80$ & 0,00 \\
\hline
\end{tabular}


o teste não foi apresentado para a investigação sobre o pessoal ocupado, uma vez que apenas um setor obteve REPQM para o período pré-tratamento menos de duas vezes superior àquela registrada para o setor de veículos. $\mathrm{O}$ valor dos REPQM pré-programa para cada modelo e setor, bem como a lista daqueles mantidos e excluídos no teste de distribuição dos placebos, consta na Tabela A.3 (Anexo).

Figura 12: Distribuição das diferenças entre os tratados e sintéticos - linha escura=veículos

(a) Custo das Operações Industriais

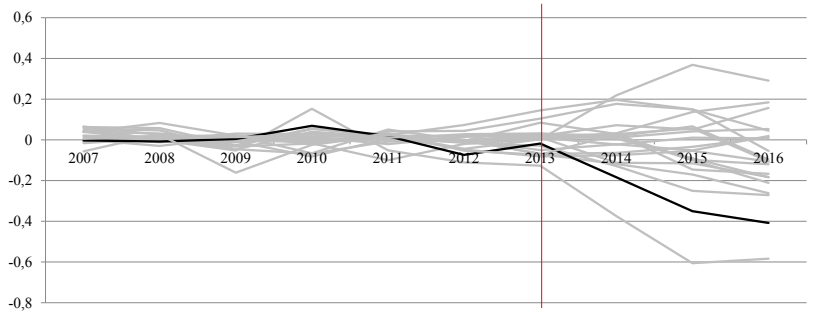

(b) Ativo Imobilizado (Aquisições e Melhorias)

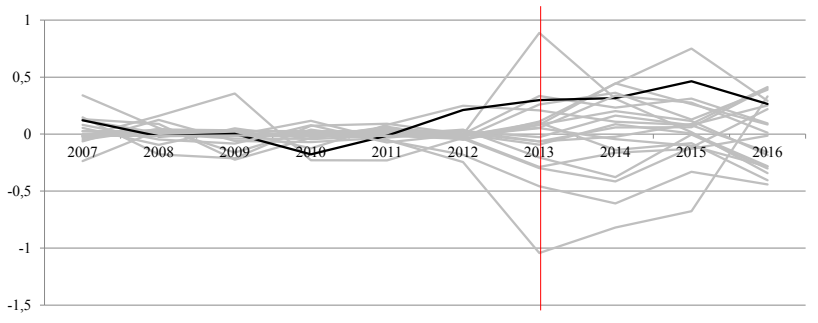

(c) Valor Adicionado Bruto

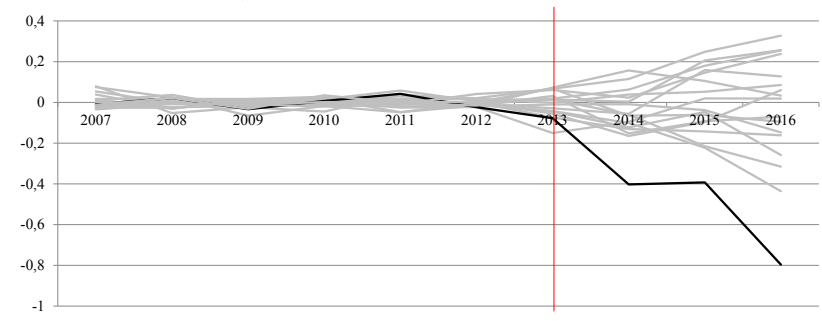

Elaboração dos autores.

\subsection{Resultados do Modelo de Diferença em Diferenças}

Na Tabela 10, podem ser observadas as estatísticas descritivas - média e desviopadrão - das variáveis de interesse e covariada usadas do modelo de diferença em diferenças quando somente o setor de fabricação de veículos automotores é considerado como unidade tratada, ou seja, afetada pela política aqui estudada. As unidades de controle são, portanto, os demais 23 setores que compõem a indústria de transformação brasileira. Os grupos de tratados e controles são apresentados separadamente.

No total, são 240 observações. No período pré-tratamento, que compreende os anos de 2007 a 2012, são 6 observações para o setor de veículos e 138 
para os demais setores e, no período pós-tratamento, de 2013 a 2016, são 4 para o setor de veículos e 92 para os demais. Para as estimações, foi feita a transformação das variáveis para seu logaritmo natural, de modo a facilitar a interpretação dos coeficientes. Assim, as estatísticas descritivas são também apresentadas nessa grandeza.

É possível observar que o setor de veículos concentra, em média, um maior número de pessoas ocupadas em relação aos demais setores, e que o número de empregados se reduziu na comparação entre o período pré e pós-implementação do programa. Entre 2007 e 2012, o número de trabalhadores era de 506,3 mil, tendo se reduzido para 475,6 mil na média dos anos de 2013 a 2016. Para os demais setores da indústria, a média de empregados aumentou de 308,6 mil para 320,2 mil nos períodos considerados.

Os dados ainda permitem verificar que o custo médio das operações industriais também é maior no setor de veículos em comparação com os demais. Em ambos os casos, houve aumento entre os períodos pré e pós-tratamento. $\mathrm{O}$ mesmo comportamento é observado nas informações referentes ao ativo imobilizado (aquisições e melhorias).

A diferença entre o valor adicionado bruto médio gerado pela indústria de veículos em relação aos demais setores da indústria de transformação é notória. No período anterior à implementação do programa, a média anual era de R\$ 53,9 bilhões no setor de veículos frente a R $\$ 19,8$ bilhões na média dos demais setores. Na média dos anos de 2013 a 2016, houve redução do valor adicionado bruto médio do setor de veículos, para $\mathrm{R} \$ 48,8$ bilhões, e aumento nos demais setores, para $\mathrm{R} \$ 27,7$ bilhões.

Por fim, os dados referentes ao número de empresas indicam que a indústria de veículos é mais concentrada em relação às demais. Entre os anos de 2007 e 2012, a média anual era de 3.741,7 empresas neste setor, frente a uma média de 7.074,7 nos demais setores. Em ambos os casos, houve aumento no período pós-implementação do programa, para 3.878 e 7.645,6, respectivamente.

Os resultados das estimações econométricas estão expostos nas Tabelas 11 a 13. Em todos os casos, é apresentado apenas o efeito do programa sobre cada uma das variáveis de interesse, de modo que os demais parâmetros estimados na equação (11) são omitidos, por economia de espaço. Dessa forma, cada resultado é advindo da estimação de uma equação. Os modelos da coluna (1) não contêm a covariada e as tendências lineares setoriais específicas e os da coluna (2) são resultantes da estimação da equação (11) em sua forma completa.

A Tabela 11 traz os efeitos do programa Inovar-Auto. Embora tenham sido apresentados os resultados da especificação sem a covariada e as tendências setoriais, a preferida para as análises é a mais completa (coluna (2)). Os parâmetros estimados se mostram estatisticamente significativos, aos níveis de $1 \%$ a $5 \%$. Podem ser considerados efeitos positivos do Inovar-Auto a redução nos custos das operações industriais (que se mostraram 6,69\% menores no grupo tratado em relação ao grupo controle) e o aumento do ativo imobilizado $(22,47 \%$ maior no grupo de tratados). Contudo, no que tange ao emprego e ao valor adicionado bruto, os efeitos do programa se mostraram negativos. $\mathrm{O}$ número de pessoas ocupadas foi $8,01 \%$ menor no grupo de tratados e o valor adicionado $13,2 \%$ menor.

Uma das possíveis explicações para esse resultado é que incentivos discricionários tendem a gerar má alocação de recursos, que tem como um de seus 
Tabela 10: Estatísticas descritivas do modelo de diferença em diferenças considerando como tratado o setor de veículos

\begin{tabular}{|c|c|c|c|c|}
\hline & \multicolumn{4}{|c|}{ Pré-Tratamento (2007 a 2012) } \\
\hline & \multicolumn{2}{|c|}{ Tratados } & \multicolumn{2}{|c|}{ Controles } \\
\hline & Média & DP & Média & DP \\
\hline Pessoal Ocupado em 31/12 (mil pessoas) & 506,3 & 37,3 & 308,6 & 295,4 \\
\hline Custo das Operações Industriais (R \$ bilhões) & 127,2 & 18,4 & 35,8 & 43,0 \\
\hline Ativo Imobilizado (Aquisições e Melhorias) (R $\$$ bilhões) & 9,4 & 3,3 & 5,4 & 9,4 \\
\hline Valor Adicionado Bruto (R\$ bilhões) & 53,9 & 8,2 & 19,8 & 17,7 \\
\hline Número de Empresas & $3.741,7$ & 173,2 & $7.074,7$ & $6.976,6$ \\
\hline \multirow[t]{4}{*}{ Número de Observações } & \multicolumn{2}{|c|}{6} & \multicolumn{2}{|c|}{138} \\
\hline & \multicolumn{4}{|c|}{ Pós-Tratamento (2013 a 2016) } \\
\hline & \multicolumn{2}{|c|}{ Tratados } & \multicolumn{2}{|c|}{ Controles } \\
\hline & Média & DP & Média & DP \\
\hline Pessoal Ocupado em 31/12 (mil pessoas) & 475,6 & 61,5 & 320,2 & 324,7 \\
\hline Custo das Operações Industriais (R $\$$ bilhões) & 149,3 & 17,6 & 52,0 & 68,8 \\
\hline Ativo Imobilizado (Aquisições e Melhorias) (R $\$$ bilhões) & 16,5 & 1,2 & 6,8 & 11,8 \\
\hline Valor Adicionado Bruto (R $\$$ bilhões) & 48,8 & 11,7 & 27,7 & 26,0 \\
\hline Número de Empresas & $3.878,0$ & 199,6 & $7.645,6$ & $7.366,8$ \\
\hline Número de Observações & \multicolumn{2}{|c|}{4} & \multicolumn{2}{|c|}{92} \\
\hline
\end{tabular}

Fonte: IBGE/PIA-Empresa. Elaboração dos autores. Obs.: DP = desvio-padrão. 
legados a acentuação ineficiência econômica, podendo culminar em redução da produção e do emprego. Como já mencionado anteriormente, é necessário cautela na análise desses números, visto que os efeitos da crise econômica não puderam ser isolados. De todo modo, pode-se argumentar que, nesse caso, o programa não teria sido capaz de reverter o impacto negativo da crise sobre o setor.

Tabela 11: Efeito do programa Inovar-Auto obtido a partir da estimação do modelo de diferença em diferenças

\begin{tabular}{lcc}
\hline & $\mathbf{( 1 )}$ & $(2)$ \\
\hline Pessoal Ocupado em 31/12 & $-0,0941^{* * *}$ & $-0,0801^{* * *}$ \\
Custo das Operações Industriais & $(0,0204)$ & $(0,0196)$ \\
& $-0,1834^{* * *}$ & $-0,0669^{* *}$ \\
Ativo Imobilizado (Aquisições e Melhorias) & $(0,0242)$ & $(0,0252)$ \\
& $\left(0,4140^{* * *}\right.$ & $0,2247^{* * *}$ \\
Valor Adicionado Bruto & $-0,4482^{* * *}$ & $(0,0638)$ \\
& $(0,0258)$ & $(0,0272)$ \\
\hline Observações & 240 & 240 \\
\hline Elaboração dos autores. (1) Modelo sem covariadas. $(2)$ Modelo com covariada \\
de número de empresas no setor mais tendência específica para cada setor. \\
Desvio-padrão entre parênteses. ${ }^{*},{ }^{* *} \mathrm{e}^{* * *}=\mathrm{p}<0,10, \mathrm{p}<0,05$ e $\mathrm{p}<0,01$, \\
respectivamente.
\end{tabular}

Para testar a robustez dos resultados obtidos, foi feito um placebo temporal. Para tanto, fez-se a suposição de que o programa tivesse sido implementado em 2009, em vez de em 2013. Claramente, para evitar a contaminação do experimento, as séries históricas foram interrompidas em 2012, último ano antes da vigência do Inovar-Auto, de modo que o número de observações se reduziu de 240 para 144 . Nesse caso, se estratégia de identificação adotada está correta, os coeficientes estimados não devem ser estatisticamente significativos.

Cabe esclarecer os dois principais motivos que levaram à escolha de 2009 para a estimação do placebo temporal. Primeiramente, uma vez que a última informação disponível é de 2016, a análise aqui apresentada contém os efeitos do programa ao longo de quatro anos (2013, 2014, 2015 e 2016). Assim, ao adotar-se 2009 como o primeiro ano de vigência do programa para o placebo, ter-se-á o mesmo horizonte temporal de análise (2009, 2010, 2011 e 2012). Ademais, em 2009 a economia brasileira também passou por uma crise, em que o setor de veículos foi mais penalizado em relação à média da indústria de transformação. ${ }^{13}$ Dessa forma, a escolha de 2009 também visa verificar, ainda que de maneira incipiente, se os efeitos da crise podem estar contidos na estimação original.

Na especificação mais completa do modelo (coluna (2) da Tabela 12), é possível notar que as estimações não são estatisticamente significativas para

\footnotetext{
${ }^{13}$ De acordo com os dados de produção física industrial (IBGE/PIM-PF), em 2009, a indústria de transformação brasileira apresentou queda de $7,0 \%$, frente a uma contração de $12,1 \%$ no setor de veículos. No acumulado de 2013 a 2016, as retrações foram de 16,5\% e 40,5\%, respectivamente. Respeitadas as diferenças de magnitude, consideravelmente mais severa na crise mais recente, nota-se que, em ambos os casos a indústria de fabricação de veículos foi mais intensamente afetada.
} 
as variáveis de emprego, custos e valor adicionado, sugerindo robustez dos resultados apresentados previamente. Contudo, para o ativo imobilizado, sobre o qual efeito do programa havia se mostrado positivo, há significância estatística no placebo, indicando que a estratégia empírica adotada não é a mais adequada no caso dessa variável.

Tabela 12: Efeito do programa Inovar-Auto obtido a partir da estimação do modelo de diferença em diferenças - Placebo Temporal

\begin{tabular}{lcc}
\hline & $(\mathbf{1})$ & $(2)$ \\
\hline Pessoal Ocupado em 31/12 & 0,0281 & $-0,0119$ \\
& $(0,022)$ & $(0,0126)$ \\
Custo das Operações Industriais & 0,0232 & 0,0303 \\
& $(0,0247)$ & $(0,0354)$ \\
Ativo Imobilizado (Aquisições e Melhorias) & 0,0559 & $-0,2880^{* * *}$ \\
& $(0,0501)$ & $(0,0705)$ \\
Valor Adicionado Bruto & $-0,0734^{*}$ & 0,0260 \\
& $(0,0388)$ & $(0,0326)$ \\
\hline Observações & 144 & 144 \\
\hline Elaboração dos autores. (1) Modelo sem covariadas. $(2)$ Modelo com \\
covariada de número de empresas no setor mais tendência específica para \\
cada setor. Desvio-padrão entre parênteses. ${ }^{*}{ }^{* *} \mathrm{e}^{* * *}=\mathrm{p}<0,10, \mathrm{p}<0,05 \mathrm{e}$ \\
p $<0,01$, respectivamente.
\end{tabular}

Por fim, também foi realizado um experimento considerando-se o efeito do programa em cada um dos anos, isoladamente, desde sua implementação. Assim, em cada um dos experimentos foi considerado todo o período préintervenção (2007 a 2012) e apenas um dos anos pós-intervenção, de modo que se obteve quatro conjuntos distintos de resultados: para 2013, para 2014, para 2015 e para 2016. Cabe ressaltar que, em todos os casos, os demais anos após a vigência do programa foram descartados da amostra, que ficaram com 168 observações. Esses resultados são apresentados na Tabela 13.

Nota-se que, em todos anos pós vigência do programa, houve efeito negativo sobre o emprego e o valor adicionado bruto, sendo que, em ambos os casos, a magnitude do impacto se intensificou ao longo do tempo. A redução dos custos das operações industriais é notada a partir do segundo ano de vigência, também se tornando mais intensa com o passar dos anos. Já sobre o ativo imobilizado se notam efeitos positivos e similares nos dois primeiros anos, se intensificando no terceiro. No último ano, o impacto torna-se estatisticamente insignificante.

\section{Considerações Finais}

O presente estudo teve como objetivo avaliar os efeitos do programa InovarAuto sobre a indústria de veículos brasileira. Para a investigação, foram utilizadas três estratégias empíricas distintas. Primeiramente, tendo como base um conjunto de dados internacionais (coletados majoritariamente junto ao Banco Mundial ao FMI), foi estimado um modelo de controle sintético para analisar o impacto sobre a produção de veículos. Duas possibilidades para a composição do conjunto de covariadas preditora foram testadas, sendo que 
Tabela 13: Efeito do programa Inovar-Auto obtido a partir da estimação do modelo de diferença em diferenças - Ano a Ano

\begin{tabular}{|c|c|c|c|c|}
\hline & \multicolumn{2}{|c|}{$2007-2012$ e 2013} & \multicolumn{2}{|c|}{$2007-2012$ e 2014} \\
\hline & $(1)$ & $(2)$ & $(1)$ & $(2)$ \\
\hline Pessoal Ocupado em 31/12 & $\begin{array}{l}-0,0146 \\
(0,0188)\end{array}$ & $\begin{array}{c}-0,0465^{\star * *} \\
(0,0163)\end{array}$ & $\begin{array}{c}-0,0802^{\star * *} \\
(0,0204)\end{array}$ & $\begin{array}{c}-0,1271^{* * *} \\
(0,0258)\end{array}$ \\
\hline Custo das Operações Industriais & $\begin{array}{c}0,0242 \\
(0,0148)\end{array}$ & $\begin{array}{c}0,0121 \\
(0,0205)\end{array}$ & $\begin{array}{c}-0,1499^{* * *} \\
(0,0216)\end{array}$ & $\begin{array}{c}-0,1696^{* * *} \\
(0,0343)\end{array}$ \\
\hline Ativo Imobilizado (Aquisições e Melhorias) & $\begin{array}{c}0,3537^{* * *} \\
(0,0577)\end{array}$ & $\begin{array}{c}0,1879^{* * *} \\
(0,0584)\end{array}$ & $\begin{array}{c}0,4033^{* * *} \\
(0,0626)\end{array}$ & $\begin{array}{l}0,1853^{* *} \\
(0,0847)\end{array}$ \\
\hline Valor Adicionado Bruto & $\begin{array}{c}-0,1457^{* * *} \\
(0,0231)\end{array}$ & $\begin{array}{l}-0,0454^{*} \\
(0,0246)\end{array}$ & $\begin{array}{c}-0,3828^{* * *} \\
(0,0224)\end{array}$ & $\begin{array}{c}-0,2596^{* * *} \\
(0,0400)\end{array}$ \\
\hline \multirow[t]{3}{*}{ Observações } & & 168 & 168 & 168 \\
\hline & \multicolumn{2}{|c|}{$2007-2012$ e 2015} & \multicolumn{2}{|c|}{$2007-2012$ e 2016} \\
\hline & $(1)$ & $(2)$ & $(1)$ & $(2)$ \\
\hline Pessoal Ocupado em 31/12 & $\begin{array}{c}-0,1356^{* * *} \\
(0,0267)\end{array}$ & $\begin{array}{c}-0,1972^{* * *} \\
(0,0405)\end{array}$ & $\begin{array}{c}-0,1461^{* * *} \\
(0,0257)\end{array}$ & $\begin{array}{c}-0,2217^{* * *} \\
(0,0465)\end{array}$ \\
\hline Custo das Operações Industriais & $\begin{array}{c}-0,3007^{* * *} \\
(0,0347)\end{array}$ & $\begin{array}{c}-0,3297^{* * *} \\
(0,0488)\end{array}$ & $\begin{array}{c}-0,3074^{* * *} \\
(0,0413)\end{array}$ & $\begin{array}{c}-0,3461^{* * *} \\
(0,0525)\end{array}$ \\
\hline Ativo Imobilizado (Aquisições e Melhorias) & $\begin{array}{c}0,5765^{* * *} \\
(0,0694)\end{array}$ & $\begin{array}{c}0,3026^{* * *} \\
(0,1018)\end{array}$ & $\begin{array}{c}0,3227^{* * *} \\
(0,0550)\end{array}$ & $\begin{array}{l}-0,0078 \\
(0,1165)\end{array}$ \\
\hline Valor Adicionado Bruto & $\begin{array}{c}-0,5757^{* * *} \\
(0,0381)\end{array}$ & $\begin{array}{c}-0,4307^{* * *} \\
(0,0499)\end{array}$ & $\begin{array}{c}-0,6887^{* * *} \\
(0,0417)\end{array}$ & $\begin{array}{c}-0,5248^{* * *} \\
(0,0709)\end{array}$ \\
\hline Observações & 168 & 168 & 168 & 168 \\
\hline
\end{tabular}

Elaboração dos autores. (1) Modelo sem covariadas. (2) Modelo com covariada de número de empresas no setor mais tendência específica para cada setor. Desvio-padrão entre parênteses. ${ }^{*},{ }^{* *} \mathrm{e}^{* * *}=\mathrm{p}<0,10, \mathrm{p}<0,05 \mathrm{e} \mathrm{p}<0,01$, respectivamente. 
em uma delas empregou-se um conjunto de variáveis macroeconômicas selecionadas e em outra se usou apenas a variável dependente defasada. O efeito encontrado foi negativo, mas não apresentou robustez, não sendo possível afirmar que houve impacto sobre essa variável.

Tendo em vista não ser possível isolar o efeito da crise que assolou a economia brasileira entre os anos de 2014 e 2016 (que coincidem com o período pós-tratamento), pode-se argumentar que não encontrar robustez no resultado estimado (negativo), ou até mesmo a ausência de um impacto positivo, seja derivado deste fato. Assim, a segunda estratégia empírica consistiu em estimar um modelo de controle sintético a partir de uma base de dados da indústria nacional.

A ideia é que, considerando-se que a crise tenha afetado a indústria como um todo, o seu impacto sobre os resultados pode ser controlado a partir dessa abordagem. Nesse caso, foram investigados os efeitos sobre o pessoal ocupado, o custo das operações industriais, o ativo imobilizado e o valor adicionado bruto. Novamente, foram testadas duas possibilidades para a composição do conjunto de covariadas preditoras, similarmente ao modelo anterior. Neste trabalho, os resultados estimados também não se mostraram robustos para o efeito (positivo) encontrado sobre o ativo imobilizado e (negativo) sobre o pessoal ocupado e os custos das operações industriais. Cabe ressaltar que a exceção se deu para o impacto negativo sobre o valor adicionado bruto, a partir do segundo ano do período pós-tratamento (2014). É preciso ressaltar que esse resultado deve ser lido com cautela, na possibilidade de a crise ter afetado o segmento de veículos mais duramente do que os outros setores da indústria nacional. Assim, ressalta-se que para o primeiro ano de vigência do programa (2013) não foram observados efeitos.

Por fim, a terceira estratégia empírica adotada foi a estimação de um modelo de diferença em diferenças. Nesse caso, investigou-se o impacto sobre o setor de veículos para as mesmas quatro variáveis analisadas no modelo de controle sintético com dados nacionais: pessoal ocupado, custo das operações industriais, ativo imobilizado e valor adicionado bruto. Foi encontrado impacto negativo sobre o custo (o que seria um resultado desejado/positivo do programa) e também impacto negativo sobre o pessoal ocupado e o valor adicionado (neste caso, indesejado). O efeito sobre o ativo imobilizado, embora positivo, não apresentou robustez. Mais uma vez, ressalta-se que esses resultados necessitam ser lidos com cautela na suposição de o setor de veículos ter sido mais afetado pela crise do que os demais, o que fica ainda mais evidente ao observar-se que a magnitude dos efeitos estimados se intensifica com o passar do tempo (e agravamento da crise).

Em resumo, a partir dos resultados obtidos na investigação aqui conduzida, não se pode concluir que o Inovar-Auto tenha apresentado efeitos sobre a produção de veículos e sobre o ativo imobilizado. Por outro lado, há indícios que tenha ocorrido redução dos custos das operações industriais, um efeito desejado do programa. Contudo, isso não se refletiu em um aumento do emprego ou do valor adicionado, havendo indícios de queda nessas dimensões investigadas. Cabe ressaltar que o estudo de Stone et al. (2015) previa que o Inovar-Auto poderia ocasionar redução dos custos, o que foi corroborado pelos resultados encontrados nesta pesquisa. Em contrapartida, a expectativa de aumento no emprego e na produção, também previstas pelos autores supracitados, não foi confirmada a partir desta investigação.

A pesquisa aqui realizada contribui para a escassa literatura nacional acerca 
dos efeitos de políticas de gasto tributário, em especial políticas de conteúdo local. Destaca-se que, apesar da prática da concessão de benefícios tributários ser adotada no país há longas décadas, poucos estudos dedicaram-se a avaliar, a partir dos ferramentais estatísticos e econométricos adequados, seus impactos. Dessa forma, acredita-se que a análise desenvolvida possa oferecer importantes subsídios para este debate.

Cabe, por fim, destacar que, evidências acerca da efetividade das políticas públicas, principalmente aquelas que concedem benefícios concentrados a regiões e/ou setores, tornam-se cada vez mais importante, especialmente no contexto atual, no qual o estabelecimento de equilíbrio nas contas públicas tem demandado um grau cada vez maior de austeridade fiscal. Formuladores de políticas têm discutido, nos últimos anos, diversas reformas estruturais, tanto de ordem microeconômica quanto macroeconômica. Assim, é fundamental que haja evidências empíricas que auxiliem no balizamento do debate, dando racionalidade às discussões.

\section{Agradecimentos}

A autora Thais Waideman Niquito agradece a bolsa de Pesquisadora Visitante do Instituto de Pesquisa Econômica Aplicada (IPEA) para a realização deste estudo. Eventuais erros e todas as opiniões são de responsabilidade integral dos autores.

\section{Referências Bibliográficas}

Abadie, A., Diamond, A. \& Hainmueller, J. (2010). Synthetic control methods for comparative case studies: estimating the effect of California's tobacco control program. Journal of the American Statistical Association, Abingdon, v. 105, p. 493-505.

Abadie, A., Diamond, A. \& Hainmueller, J. (2015). Comparative politics and the synthetic control method. American Journal of Political Science, Hoboken, v. 59, p. 495-510.

Abadie, A. \& Gardeazabal, J. (2003). The economic costs of conflict: a case study of the Basque Country. American Economic Review, Nashville, v. 93, p. 113-132.

ANFAVEA - Associação Nacional dos Fabricantes de Veículos Automotores (2017). Anuário da Indústria Automobilística Brasileira: 2017. São Paulo.

ANFAVEA - Associação Nacional dos Fabricantes de Veículos Automotores (2020). Anuário da Indústria Automobilística Brasileira: 2020. São Paulo.

Bartelsman, E., Haltiwanger, J. \& Scarpetta, S. (2013). Cross-country differences in productivity: the role of allocation and selection. American Economic Review, Nashville, v. 103, p. 305-34.

Bertrand, M., Duflo, E. \& Mullainathan, S. (2004). How much should we trust differences-in-differences estimates? The Quarterly Journal of Economics, Cambridge, v. 119, p. 249-275.

Botosaru, I. \& Ferman, B. (2019). On the role of covariates in the synthetic control method. The Econometrics Journal, Oxford, v. 22, p. 117-130. 
Brasil (2012). Lei $\mathrm{n}^{\circ} 12.715$, de 17 de setembro de 2012. Altera a alíquota das contribuições previdenciárias sobre a folha de salários devidas pelas empresas que especifica; institui o Programa de Incentivo à Inovação Tecnológica e Adensamento da Cadeia Produtiva de Veículos Automotores; e dá outras providências. Diário Oficial da República Federativa do Brasil, Brasília. Disponível em: https://www.planalto.gov.br/ccivil_03/_ato2011-2014/2012/Lei / L12715.htm.

Brasil (2018). Lei no 13.755, de 10 de dezembro de 2018. Estabelece requisitos obrigatórios para a comercialização de veículos no Brasil; e dá outras providências. Diário Oficial da República Federativa do Brasil, Brasília. Disponível em: http://www.planalto.gov.br/ccivil_03/_ato2015-2018/2018/lei/L13755. htm.

Brasil (2019). Avaliação de impacto do programa Inovar-Auto. Brasília: Grupo de Acompanhamento do Programa Inovar-Auto.

Cavallo, E., Galiani, S., Noy, I. \& Pantano, J. (2013). Catastrophic natural disasters and economic growth. Review of Economics and Statistics, Cambridge, v. 95 , p. $1549-1561$.

Doudchenko, N. \& Imbens, G. W. (2016). Balancing, regression, differencein-differences and synthetic control methods: a synthesis. Cambridge: National Bureau of Economic Research. (Working Paper n. 22791).

Gobillon, L. \& Magnac, T. (2016). Regional policy evaluation: interactive fixed effects and synthetic controls. Review of Economics and Statistics, Cambridge, v. 98 , p. $535-551$.

Grossman, G. M. (1981). The theory of domestic content protection and content preference. The Quarterly Journal of Economics, Cambridge, v. 96, p. 583-603.

Hsieh, C.-T. \& Klenow, P. J. (2009). Misallocation and manufacturing TFP in China and India. The Quarterly Journal of Economics, Cambridge, v. 124, p. 1403-1448.

IMF (2020). World Economic Outlook Database. Washington: International Monetary Fund.

Kuntze, J.-C. \& Moerenhout, T. (2012). Local Content Requirements and the Renewable Energy Industry-A Good Match? New York: SSRN. Disponível em: https: //ssrn.com/abstract=2188607.

Marx, R. \& Mello, A. M. (2014). New initiatives, trends and dilemmas for the Brazilian automotive industry: the case of Inovar Auto and its impacts on electromobility in Brazil. International Journal of Automotive Technology and Management 21, Genebra, v. 14, p. 138-157.

Messa, A. (2013). Impacto de políticas de exigência de conteúdo local: o caso do programa Inovar-Auto. In: Messa, A.; Oliveira, I. T. M. (orgs.) A Política Comercial Brasileira em Análise. Brasília: Instituto de Pesquisa Econômica Aplicada (Ipea). v. 1. 
Myles, G. D., Hashimzade, N., Heady, C., Oats, L., Scharf, K. \& Yousefi, H. (2014). The definition, measurement, and evaluation of tax expenditures and tax reliefs. London: National Audit Office.

Palmeri, N. L. (2017). O impacto do programa Inovar-Auto na indústria automotiva brasileira. 2017. Tese (Doutorado em Engenharia de Produção) - Programa de Pós-Graduação em Engenharia de Produção da Universidade Paulista (UNIP), São Paulo. Disponível em: http://repositorio.unip.br/programa-de-pos-graduacao-stricto-sensu-emengenharia-de-producao/o-impacto-do-programa-inovar-auto-na-industriaautomotiva-brasileira/.

Possebom, V. (2017). Free trade zone of Manaus: an impact evaluation using the synthetic control method. Revista Brasileira de Economia, Rio de Janeiro, v. 71 , p. $217-231$.

Restuccia, D. \& Rogerson, R. (2008). Policy distortions and aggregate productivity with heterogeneous establishments. Review of Economic Dynamics, Amsterdam, v. 11, 4, p. 707-720.

Restuccia, D. \& Rogerson, R. (2017). The causes and costs of misallocation. Journal of Economic Perspectives, Nashville, v. 31, p. 151-74.

Santos, A. M. M. M. \& Pinhão, C. M. A. (1999). Pólos automotivos brasileiros. BNDES Setorial, Rio de Janeiro, p. 173-200.

Stone, S., Messent, J. \& Flaig, D. (2015). Emerging policy issues: localisation barriers to trade. Paris: OECD. (Trade Policy Papers n. 180).

Sturgeon, T., Lima Chagas, L. \& Barnes, J. (2017). Inovar Auto: Evaluating Brazil's Automative Industrial Policy to Meet the Challenges of Global Value Chains. Washington, DC: World Bank.

Tordo, S., Warner, M., Manzano, O. \& Anouti, Y. (2013). Local Content Policies in the Oil and Gas Sector. Washington, DC: World Bank.

\section{Anexo}


Tabela A.1: Controle sintético com dados internacionais (países) Raiz do Erro de Previsão Quadrático Médio pré-tratamento

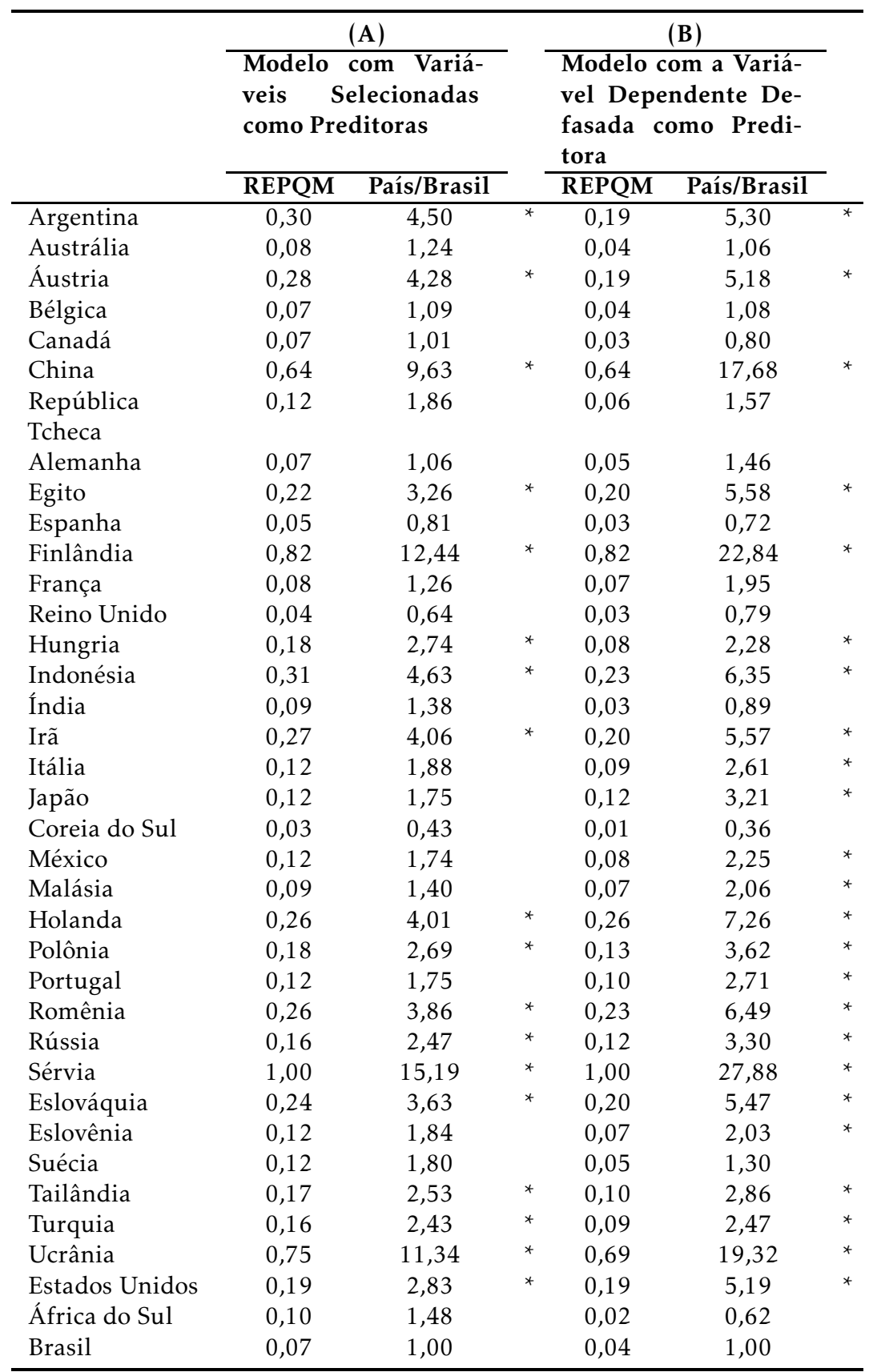

Elaboração dos autores.

$\left.{ }^{*}\right)$ = países excluídos dos placebos, por apresentarem REPQM mais de duas vezes superior à REPQM do Brasil. 
Tabela A.2: Controle sintético com dados dos setores da indústria nacional - Raiz do Erro de Previsão Quadrático Médio pré-tratamento - variáveis de interesse e número de empresas utilizados como preditores

\begin{tabular}{|c|c|c|c|c|c|c|c|c|c|c|c|c|c|}
\hline & & \multicolumn{12}{|c|}{ Variáveis de interesse } \\
\hline & & \multicolumn{2}{|c|}{$\begin{array}{l}\text { Pessoal Ocupado em } \\
31 / 12\end{array}$} & & \multicolumn{2}{|c|}{$\begin{array}{l}\text { Custo das Operações } \\
\text { Industriais }\end{array}$} & & \multicolumn{2}{|c|}{$\begin{array}{l}\text { Ativo Imobilizado } \\
\text { (Aquisiçôes e Melho- } \\
\text { rias) }\end{array}$} & & \multicolumn{2}{|l|}{$\begin{array}{l}\text { Valor } \\
\text { Bruto }\end{array}$} & \\
\hline & & REPQM & $\begin{array}{l}\text { (setor)/ } \\
(29)\end{array}$ & & REPQM & $\begin{array}{l}\text { (setor)/ } \\
\text { (29) }\end{array}$ & & REPQM & $\begin{array}{l}\text { (setor) } / \\
(29)\end{array}$ & & REPQM & $\begin{array}{l}\text { (setor)/ } \\
(29)\end{array}$ & \\
\hline 10 & Fabricação de produtos alimentícios & $\overline{0,83}$ & 45,19 & & 0,59 & 8,24 & & 0,09 & 0,45 & & 0,33 & 8,69 & * \\
\hline 11 & Fabricação de bebidas & 0,10 & 5,56 & * & 0,10 & 1,47 & & 0,27 & 1,37 & & 0,12 & 3,23 & * \\
\hline 12 & Fabricação de produtos do fumo & 1,64 & 89,58 & * & 0,09 & 1,29 & & 0,56 & 2,86 & * & 0,44 & 11,57 & * \\
\hline 13 & Fabricação de produtos têxteis & 0,04 & 2,38 & * & 0,05 & 0,77 & & 0,10 & 0,50 & & 0,04 & 1,00 & \\
\hline 14 & Confecção de artigos do vestuário e acessórios & 0,04 & 2,09 & * & 0,08 & 1,14 & & 0,09 & 0,44 & & 0,10 & 2,64 & * \\
\hline 15 & $\begin{array}{l}\text { Preparação de couros e fabricação de artefatos de couro, artigos para viagem } \\
\text { e calçados }\end{array}$ & 0,04 & 2,41 & * & 0,10 & 1,41 & & 0,18 & 0,92 & & 0,02 & 0,61 & \\
\hline 16 & Fabricação de produtos de madeira & 0,10 & 5,59 & * & 0,14 & 2,00 & * & 0,29 & 1,51 & & 0,14 & 3,74 & * \\
\hline 17 & Fabricação de celulose, papel e produtos de papel & 0,03 & 1,37 & & 0,04 & 0,56 & & 0,32 & 1,63 & & 0,05 & 1,21 & \\
\hline 18 & Impressão e reproduçấo de gravações & 0,08 & 4,48 & * & 0,11 & 1,58 & & 0,30 & 1,52 & & 0,09 & 2,33 & * \\
\hline 19 & $\begin{array}{l}\text { Fabricação de coque, de produtos derivados do petróleo e de biocombustí- } \\
\text { veis }\end{array}$ & 0,18 & 10,01 & * & 0,10 & 1,39 & & 0,87 & 4,43 & * & 0,30 & 7,95 & * \\
\hline 20 & Fabricação de produtos químicos & 0,03 & 1,74 & & 0,05 & 0,64 & & 0,11 & 0,55 & & 0,14 & 3,60 & * \\
\hline 21 & Fabricação de produtos farmoquímicos e farmacêuticos & 0,03 & 1,50 & & 0,07 & 1,01 & & 0,22 & 1,13 & & 0,05 & 1,44 & \\
\hline 22 & Fabricação de produtos de borracha e de material plástico & 0,04 & 1,97 & & 0,03 & 0,43 & & 0,20 & 1,05 & & 0,03 & 0,75 & \\
\hline 23 & Fabricação de produtos de minerais não metálicos & 0,11 & 5,91 & * & 0,12 & 1,74 & & 0,26 & 1,32 & & 0,10 & 2,60 & * \\
\hline 24 & Metalurgia & 0,03 & 1,69 & & 0,06 & 0,82 & & 0,23 & 1,16 & & 0,18 & 4,76 & * \\
\hline 25 & Fabricação de produtos de metal, exceto máquinas e equipamentos & 0,04 & 2,45 & * & 0,05 & 0,76 & & 0,08 & 0,41 & & 0,08 & 2,01 & * \\
\hline 26 & Fabricação de equipamentos de informática, produtos eletrônicos e ópticos & 0,04 & 2,38 & * & 0,05 & 0,75 & & 0,20 & 1,03 & & 0,08 & 1,99 & \\
\hline 27 & Fabricação de máquinas, aparelhos e materiais elétricos & 0,05 & 2,74 & * & 0,08 & 1,15 & & 0,14 & 0,72 & & 0,10 & 2,52 & * \\
\hline 28 & Fabricação de máquinas e equipamentos & 0,04 & 2,10 & * & 0,09 & 1,28 & & 0,13 & 0,66 & & 0,04 & 1,05 & \\
\hline 29 & Fabricação de veículos automotores, reboques e carrocerias & 0,02 & 1,00 & & 0,07 & 1,00 & & 0,20 & 1,00 & & 0,04 & 1,00 & \\
\hline 30 & $\begin{array}{l}\text { Fabricação de outros equipamentos de transporte, exceto veículos automo- } \\
\text { tores }\end{array}$ & 0,09 & 4,99 & * & 0,05 & 0,75 & & 0,47 & 2,42 & * & 0,08 & 2,03 & * \\
\hline 31 & Fabricação de móveis & 0,07 & 3,84 & * & 0,09 & 1,32 & & 0,19 & 0,98 & & 0,08 & 2,14 & * \\
\hline 32 & Fabricação de produtos diversos & 0,06 & 3,39 & * & 0,09 & 1,20 & & 0,14 & 0,74 & & 0,07 & 1,78 & \\
\hline 33 & Manutenção, reparação e instalação de máquinas e equipamentos & 0,09 & 4,64 & * & 0,10 & 1,43 & & 0,33 & 1,69 & & 0,03 & 0,89 & \\
\hline
\end{tabular}

Elaboração dos autores.

$\left({ }^{*}\right)=$ setores excluídos dos placebos, por apresentarem REPQM mais de duas vezes superior à REPQM de veículos. 
Tabela A.3: Controle sintético com dados dos setores da indústria nacional - Raiz do Erro de Previsão Quadrático Médio pré-tratamento - variável de interesse defasada utilizada como preditor

\begin{tabular}{|c|c|c|c|c|c|c|c|c|c|c|c|c|c|}
\hline & & \multicolumn{11}{|c|}{$\begin{array}{l}\text { Variáveis de interesse } \\
\end{array}$} & \\
\hline & & \multicolumn{2}{|c|}{$\begin{array}{l}\text { Pessoal Ocupado em } \\
31 / 12\end{array}$} & & \multicolumn{2}{|c|}{$\begin{array}{l}\text { Custo das Operações } \\
\text { Industriais }\end{array}$} & & \multicolumn{2}{|c|}{$\begin{array}{l}\text { Ativo Imobilizado } \\
\text { (Aquisiçôes e Melho- } \\
\text { rias) }\end{array}$} & & $\begin{array}{l}\text { Valor } \\
\text { Bruto }\end{array}$ & Adicionado & \\
\hline & & REPQM & $\begin{array}{l}(\text { setor } / / \\
(29)\end{array}$ & & REPQM & $\begin{array}{l}\text { (setor)/ } \\
(29)\end{array}$ & & REPQM & $\begin{array}{l}\text { (setor)t } \\
(29)\end{array}$ & & REPQM & $\begin{array}{l}\text { (setor)/ } \\
\text { (29) }\end{array}$ & \\
\hline 10 & Fabricaçâo de produtos alimentícios & 0,83 & $\frac{127}{1.085,04}$ & $*$ & 0,59 & 13,94 & & 0,03 & 0,27 & & $\overline{0,32}$ & 12,42 & \\
\hline 11 & Fabricação de bebidas & 0,01 & 10,35 & * & 0,03 & 0,66 & & 0,14 & 1,12 & & 0,01 & 0,45 & \\
\hline 12 & Fabricação de produtos do fumo & 1,64 & $2.150,92$ & * & 0,08 & 2,00 & & 0,56 & 4,59 & * & 0,44 & 16,94 & * \\
\hline 13 & Fabricação de produtos têxteis & 0,01 & 7,01 & * & 0,01 & 0,29 & & 0,00 & 0,00 & & 0,00 & 0,00 & \\
\hline 14 & Confecção de artigos do vestuário e acessórios & 0,01 & 19,28 & * & 0,03 & 0,83 & & 0,02 & 0,18 & & 0,06 & 2,38 & * \\
\hline 15 & $\begin{array}{l}\text { Preparação de couros e fabricação de artefatos de couro, artigos para viagem } \\
\text { e calçados }\end{array}$ & 0,01 & 14,89 & * & 0,03 & 0,80 & & 0,00 & 0,00 & & 0,00 & 0,00 & \\
\hline 16 & Fabricação de produtos de madeira & 0,03 & 44,03 & * & 0,04 & 1,05 & & 0,12 & 0,96 & & 0,05 & 1,80 & \\
\hline 17 & Fabricação de celulose, papel e produtos de papel & 0,00 & 0,74 & & 0,02 & 0,43 & & 0,21 & 1,71 & & 0,02 & 0,84 & \\
\hline 18 & Impressão e reprodução de gravaçōes & 0,02 & 31,14 & * & 0,10 & 2,29 & * & 0,12 & 1,02 & & 0,07 & 2,82 & * \\
\hline 19 & $\begin{array}{l}\text { Fabricação de coque, de produtos derivados do petróleo e de biocombustí- } \\
\text { veis }\end{array}$ & 0,15 & 193,25 & * & 0,06 & 1,35 & & 0,87 & 7,11 & * & 0,28 & 10,86 & \\
\hline 20 & Fabricacão de produtos químicos & 0,00 & 5,39 & * & 0,04 & 0,97 & & 0,03 & 0,26 & & 0,05 & 1,81 & \\
\hline 21 & Fabricação de produtos farmoquímicos e farmacêuticos & 0,01 & 10,50 & * & 0,00 & 0,05 & & 0,02 & 0,19 & & 0,02 & 0,83 & \\
\hline 22 & Fabricação de produtos de borracha e de material plástico & 0,01 & 7,93 & * & 0,00 & 0,05 & & 0,07 & 0,57 & & 0,00 & 0,16 & \\
\hline 23 & Fabricação de produtos de minerais não metálicos & 0,02 & 20,58 & * & 0,04 & 0,92 & & 0,15 & 1,26 & & 0,01 & 0,55 & \\
\hline 24 & Metalurgia & 0,01 & 8,04 & * & 0,04 & 1,04 & & 0,17 & 1,43 & & 0,16 & 6,18 & * \\
\hline 25 & Fabricação de produtos de metal, exceto máquinas e equipamentos & 0,00 & 4,98 & * & 0,01 & 0,22 & & 0,03 & 0,22 & & 0,00 & 0,15 & \\
\hline 26 & Fabricação de equipamentos de informática, produtos eletrônicos e ópticos & 0,01 & 11,17 & * & 0,01 & 0,30 & & 0,03 & 0,24 & & 0,02 & 0,94 & \\
\hline 27 & Fabricação de máquinas, aparelhos e materiais elétricos & 0,01 & 13,88 & * & 0,01 & 0,18 & & 0,05 & 0,45 & & 0,02 & 0,79 & \\
\hline 28 & Fabricação de máquinas e equipamentos & 0,01 & 18,94 & * & 0,03 & 0,64 & & 0,00 & 0,00 & & 0,03 & 1,01 & \\
\hline 31 & Fabricação de móveis & 0,01 & 8,61 & * & 0,01 & 0,14 & & 0,00 & 0,03 & & 0,05 & 2,07 & * \\
\hline 32 & Fabricação de produtos diversos & 0,02 & 24,23 & * & 0,08 & 1,91 & & 0,07 & 0,55 & & 0,02 & 0,76 & \\
\hline 33 & Manutenção, reparação e instalação de máquinas e equipamentos & 0,05 & 65,70 & * & 0,09 & 2,06 & * & 0,32 & 2,65 & * & 0,01 & 0,56 & \\
\hline
\end{tabular}

Elaboração dos autores.

$\left({ }^{*}\right)=$ setores excluídos dos placebos, por apresentarem REPQM mais de duas vezes superior à REPQM de veículos. 